\title{
Consumer ethnicity three decades after: A TCR agenda
}

Luca M. Visconti*, ESCP Europe, 79 avenue de la République - 75011 Paris (France), lvisconti@escpeurope.eu, tel.003314923.5874

Aliakbar Jafari, University of Strathclyde, UK, Department of Marketing, Sir William Duncan Building, 130 Rottenrow Street, Glasgow, G4 0GE, aliakbar.jafari@strath.ac.uk

Wided Batat, University of Lyon 2, France, Campus Porte des Alpes, 5 Avenue Pierre MendèsFrance, 69676 Bron Cedex, France, wided.batat@univ-lyon2.fr

Aurelie Broeckerhoff, Coventry Buss School, Priory Street - Coventry CV1 5FB (UK) aurelie.broeckerhoff@coventry.ac.uk

Ayla Özhan Dedeoglu, Ege University, TR, Department of Marketing, Ege University Iktisadi ve Idari Bilimler Fakultesi Bornova Izmir, 35040, Turkey, ayla.dedeoglu@ege.edu.tr

Catherine Demangeot, Strathclyde Business School, Department of Marketing, Stenhouse Building, 173 Cathedral Street, Glasgow G4 0RQ, (UK), catherine.demangeot@strath.ac.uk.

Eva Kipnis, Coventry Business School, Coventry University. Priory street, Coventry, CV1 5FB,yeva.kipnis2@coventry.ac.uk

Andrew Lindridge, The Open University Business School, Michael Young Building, Walton hall, Milton Keynes, MK7 6AA (United Kingdom), andrew.lindridge@open.ac.uk

Lisa Peñaloza, Kedge Business School, Department of Marketing and Consumer Relations, 680 Cours de la Liberation - 33405 Talence (France), lisa.peñaloza@kedgebs.com.

Chris Pullig, Hankamer School of Business, Baylor University, One Bear Place \#98007, Waco, Texas 76798,Chris_Pullig@Baylor.edu.

Fatima Regany, Université Lille 2/IMMD, 6 rue de l'Hôtel de Ville - 59051 Roubaix (France), fatima.regany-2@univ-lille2.fr.

Elif Ustundagli, Ege University, Ege Universitesi, Iktisadi ve Idari Bilimler Fakultesi, Isletme Bolumu,35100 Bornova, Izmir, Turkiye, elif.ustundagli@ege.edu.tr

Michelle F. Weinberger, Northwestern University, Medill School of Journalism, Media, Integrated Marketing Communications, Evanston, Illinois 60202, m-weinberger@northwestern.edu

* Contact author 


\section{About the authors}

Luca M. Visconti is Associate Professor of Marketing at ESCP Europe, Paris campus, and Professor at IFM - Institut Français de la Mode, Paris. He holds a Ph.D. in Business Administration and Management from Università Bocconi, Milan. His research involves the consumption of market minorities (migrants, gays, elderly consumers, bottom-of-the-pyramid consumers) as well as the consumption of collective goods (public space and public health). His research has appeared in the Journal of Consumer Research (2010; 2014), Journal of Macromarketing (in press), Journal of Consumer Behavior (in press), Journal of Business Research (2012), Journal of Consumer Culture (2011), Journal of Advertising (2010), Industrial Marketing Management (2010), and Consumption, Markets \& Culture (2008). His latest edited book is Marketing Management: A Cultural Perspective (with L. Peñaloza and N. Toulouse).

Aliakbar Jafari is a Chartered Fellow of the Chartered Institute of Marketing and Senior Lecturer in marketing at the University of Strathclyde. His research interests fall within the interpretive consumer research tradition with a focus on institutional theory, theories of globalisation, religions/spirituality, and politics and policies of consumption. His work has appeared in Marketing Theory; Consumption, Markets \& Culture; Journal of Marketing Management; The Sociological Review; Journal of Islamic Marketing; International Journal of Management Concepts and Philosophy; Journal of Macromarketing; European Journal of Marketing; and Tourism Management. Currently, he is co-editing Critical Perspectives on Islamic Marketing (with Ö. Sandıç̧1) and the four-volume set of New Directions in Consumer Research (with P. Hewer and K. Hamilton).

Wided Batat, Ph.D., is Associate Professor of Marketing at the University of Lyon 2 (France) as well as a United Nations Representative of the International Federation for Home Economics IFHE at the UNESCO in Paris. Her research looks after young consumer education and the ethical implications, consumption cultures, ethnicity, subcultures, vulnerability and well-being, consumption meanings, and experiential consumption. Furthermore, Dr. Batat developed a keen interest in subjectivist research methodologies such as personal introspection, phenomenology, and ethnography. Her works have been published in French and English academic journals such as Recherches et Application en Marketing, International Journal for Consumer Studies, Advances in Consumer Research, Journal of Business Research, Journal of Research for Consumers, Journal of Communications of the IBIMA, etc.

Aurelie Broeckerhoff is Senior Research Assistant at the Centre for Trust, Peace and Social Relations and doctoral student at Coventry Business School. She holds a Master degree from Humboldt University, Berlin, Germany. Her professional background lies in international and intercultural relations, working with the British Council and the Institute of Foreign Cultural Relations (ifa), as well as in social and integration policy, working for the Institute of Community Cohesion (iCoCo). Her doctoral research explores how pace and nature of the changes that people experience in their everyday lives are reflected in the consumption patterns of people within diverse neighborhoods. She has co-authored two books: Options for Influence (with A. Fisher) on international relations and public diplomacy and Volunteering: Global Citizenship in Action (with N. Wadham-Smith) on the impact of international exchange on civil society.

Ayla Özhan Dedeoglu is a Professor in Marketing at Ege University. Her research interests fall within the interpretive consumer research tradition with a focus on modernity and consumer 
identity projects. She has published in Asia-Pacific Advances in Consumer Research, Journal of Euro-Marketing, and Journal of Business, Economics and Management.

Catherine Demangeot is a Senior Lecturer of Marketing at Strathclyde Business School. She received a PhD in Marketing from Aston Business School. Her research interests lie in the area of consumers' interactions with multi-cultural or virtual environments, as well as the strategies they may deploy and the competences they may acquire in the process. Her research has been published in the Journal of Public Policy and Marketing, Psychology \& Marketing, the Journal of Business Research, the Journal of Marketing Management and other international publications. She is the recipient of the British Academy of Management's 2008 Tony Beasley Award in recognition of outstanding work derived from doctoral research. Catherine spent her 'first life' in print and web publishing, in London and Dubai.

Eva Kipnis is a Senior Lecturer in Marketing at Coventry Business School, UK, and doctoral candidate at University of Durham, UK. Her research is focused in three inter-related areas: multicultural people - their identities, experiences and consumption; cultural and multicultural branding - approaches and implications; organizations in multicultural marketplacesdevelopment of organizational capabilities to create multiculturally-competent advertising and communication. Her work appeared in the Journal of Marketing Management, Journal of Business Research, Consumption, Markets \& Culture, Journal of Public Policy and Marketing and others.

Andrew Lindridge is a Senior Lecturer in Marketing at The Open University Business School. His research interests include: tensions arising from acculturation, the role of religion in consumption, racism in service encounters and the role of inherited and personal trauma. His work has appeared in refereed journals including the Consumption, Markets \& Culture, European Journal of Marketing, Journal of Business Research, Journal of Consumer Marketing and the Journal of Marketing Management. He has presented papers at a number of international conferences including the Association for Consumer Research, Consumer Culture Theory, and the European Marketing Academy (EMAC).

Lisa Peñaloza is Professor at Kedge Business School, Bordeaux, France; and Senior Researcher at the Center for Consumer Culture Theory, Stockholm Business School. Her research examining the acquisition, reproduction, and navigation of cultural meanings and economic values by consumers and marketers across various subcultural and organizational domains has appeared in such journals as Consumption, Markets \& Culture, Marketing Theory, Journal of Public Policy and Marketing, Journal of Consumer Research, and Journal of Marketing. She also disseminates her research in documentary film and theatre. She is former editor of Consumption, Markets \& Culture, and editor of the textbook, Marketing Management: A Cultural Perspective, with Nil Toulouse and Luca M. Visconti (Routledge, 2011).

Chris Pullig is Associate Professor and Chair of Marketing in the Hankamer School of Business at Baylor University. His research focuses on brand-related consumer judgments with a special emphasis on the positive role of brands in the global marketplace. His research has appeared in a variety of journals including the Journal of Marketing, Journal of Consumer Psychology, Journal of the Academy of Marketing Science, Journal of Retailing, Journal of Business Ethics, Journal of Business Research, Journal of Public Policy and Marketing, and others. 
Fatima Regany is Assistant Professor of Marketing at University of Lille 2/IMMD (Institut du Marketing et du Management de la Distribution). She holds a Ph.D. in Management and Marketing from University of Lille 2 (France). Her research focuses on the consumption of migrants and their cultural identities, intergenerational relationships, and gender spaces. Her research has been presented in French and international conferences, and appears in book chapters.

Elif Ustundagli is a PhD student and Research Assistant at Ege University in İmir, Turkey. Her dissertation focuses on (multiple)modernity and consumer participation in dual cultures in the context of a religious minority group (Jewish community in İzmir). Her general research interest involves consumption of minorities, gender, acculturation, and religion in interpretive consumer research.

Michelle Weinberger is an Assistant Professor at Northwestern University in the Medill School's Integrated Marketing Communication department. Her research on consumer culture takes a sociological perspective, examining topics such as the consumption of experiences and inequality, consumption rituals, gift giving, and the socio-cultural process of innovation. Her work has appeared in the Journal of Consumer Research and has been presented at the Association for Consumer Research, Consumer Culture Theory, and the American Sociological Association conferences. 


\title{
Consumer ethnicity three decades after: A TCR agenda
}

\begin{abstract}
Research into consumer ethnicity is a vital discipline that has substantially evolved in the past three decades. This conceptual article critically reviews its immense literature and examines the extent to which it has provided extensive contributions not only for the understanding of ethnicity in the marketplace but also for personal/collective wellbeing. We identify two gaps accounting for scant transformative contributions. First, today social transformations and conceptual sophistications require a revised vocabulary to provide adequate interpretive lenses. Second, extant work has mostly addressed the subjective level of ethnic identity projects but left untended the meso/macro forces affecting ethnicity (de)construction and personal/collective wellbeing. Our contribution stems from filling both gaps and providing a theory of ethnicity (de)construction that includes migrants as well as non-migrants.
\end{abstract}

\section{Summary statement of contribution}

We contribute primarily to setting the ground for a TCR orientation of research into consumer ethnicity. Through the identification of two substantive gaps (narrow and misleading vocabulary and micro focus predominance), we also offer a revisited vocabulary on ethnicity and a holistic model of the macro forces involved in ethnicity (de)construction. Both contributions foster a transformative agenda for future research and offer implications for both policy-makers and different stakeholders whose ethnic orientation/structure necessitates achieving wellbeing.

\section{Keywords}

Acculturation; consumer acculturation; ethnicity; immigration; transformative consumer research; wellbeing. 


\section{Three decades after}

'These are more than interesting times' (Mick, 2008, p. 377). More than three decades of research into consumer ethnicity offer today an abundance of perspectives on how, why, and with what effects people elaborate, negotiate, transform, and commodify their ethnicity in the marketplace (for an updated overview see Jamal, Peñaloza, \& Laroche, in press). We agree with Mick that it is time for a critical reconsideration of consumer research and more specifically, for our aims, research into consumer ethnicity. Luedicke's 2011 article — on which this article elaboratesillustrates the state of the art of the field comprehensively and critically. To date, research into consumer ethnicity has mostly focused on: (1) ethnic minorities' distinctive consumption patterns (1981-1988) (Desphande, Hoyer, \& Donthu, 1986; Henstorf, Martinez, \& Merino 2012; Hirschman, 1981); (2) the multiple adaptation strategies that migrants undergo to accommodate to a new (market) culture (1989-2006) (Askegaard, Arnould, \& Kjeldgaard, 2005; Lindridge, Hogg, \& Shah, 2004; Oswald, 1999; Peñaloza, 1989, 1994); and (3) the role of macro institutional forces in the (de)construction of ethnicity (2007-present) (Jafari \& Goulding, 2008; Üstüner \& Holt, 2007; Üstüner and Thompson, 2012; Visconti, in press).

Despite substantive theoretical advances, Luedicke (2011, p. 231) denounces that research into consumer ethnicity has seldom 'developed implications for political or social remediation'. In line with the Journal of Marketing Management's special issue on Transformative Consumer Research (TCR) (Mick, 2006; Mick, Pettigrew, Pechmann, \& Ozanne, 2012; Ozanne, 2011) and Luedicke's call for more dedicated research on ethnicity and wellbeing, this article addresses the broad question: How can we propagate a TCR agenda in research into consumer ethnicity? We identify three main aspects that are problematic for the development of a TCR-orientation in the field. All are grounded on Luedicke's (2011) above-mentioned diagnosis: (1) lack of conceptual clarity and completeness; (2) paucity of studies maintaining a holistic macro perspective on 
ethnicity; and (3) focus on migrants' acculturation, thus leaving untended discussion about nonmigrants' ethnicity.

First, despite its three decades of life, research into consumer ethnicity has produced a number of contributions built on constructs that are sometimes confusing as well as incomplete. Confusion occurs because the same construct can assume different, and even competing, meanings. For example, ethnicity has been used either to describe an objectively stated position a person occupies in the social ordering (Laroche et al., 1998) or a subjectively chosen option (Song, 2003; Stayman \& Deshpande, 1989; Waters, 1990). Ethnicity has also been defined as either a system of shared 'cultural characteristics' (Healey, 2012, p. 16) or the origin of 'structured social inequalities' (Aronowitz, 1992, p. 53), thus shifting its foundation from cultural to social categories respectively. Race, often associated with ethnicity, has been presented as a biological (Cornell \& Hartmann, 1998), political (Aronowitz, 1992), and even socially constructed (Golberg, 1992) category. Beyond clarity, conceptual incompleteness also conditions theoretical robustness of research into consumer ethnicity. For example, extant studies mainly rely on binary oppositions, such as the 'home'/'host', 'origin'/'destination', 'minority'/'mainstream', and 'dominant'/'dominated' divide (Dandy \& Pe-Pua, 2010). In the interest of simplification, binary oppositions can undermine theoretical robustness and reproduce stereotypes and prejudices (Askegaard et al., 2005), thus impairing personal and collective wellbeing. Among others, separation between 'home'/'host' culture may be reasonable for a long-term migrant but does not look so appropriate to describe the situation of second generations (Rumbaut, 1994) or that of people only temporarily sojourning abroad (Sussman, 2002a). Therefore, the first section of this article refines the vocabulary on ethnicity used in our field, whilst trying at the same time to attribute univocal meanings to key constructs and to enlarge our vocabulary in order to acknowledge the variety of ethnic positions we observe in contemporary 
markets. This should provide a more inclusive theoretical framework from which scholars can build future TCR research.

Second, research into consumer ethnicity has only recently started to inquire into the role of macro institutional forces in the (de)construction of ethnicity in the marketplace. Yet, those studies holding a macro perspective tend to focus on one macro force at a time: the theocratic system in which ethnicity is shaped (Jafari \& Goulding, 2008); space (Visconti, in press) and spatial segregation (Üstüner \& Holt, 2007) embedding ethnicity; status games (Üstüner and Thompson, 2012); the impact of a shared capitalist ideology on ethnic identity (Peñaloza and Barnahart, 2011); and the role of marketplace agents on ethnic accommodation (Peñaloza, 2007; Peñaloza and Gilly, 1999). If transformative implications have to be drawn, our field needs to provide a holistic model of the macro forces at play in the construction, use, and commodification of ethnicity. As such, the second section of this article proposes an overarching model in which we include the main macro forces that extant research suggests as relevant in the continuous making of ethnicity in the marketplace. While the field often presents ethnicity as an immutable reference in consumer life, the model adds dynamism to understandings of the construct. In doing so, we address the call for more intersectional ethnic research suggested as a better way to support implications for consumer wellbeing (Crockett et al., 2011).

Third, research into consumer ethnicity has long explored the construction, accommodation, and role of ethnicity in the life of migrants (Oswald, 1999; Peñaloza, 1994). As Bouchet (1995) notes, dictionaries themselves define ethnicity as a quality and affiliation that characterize members of minority groups. This position reflects an 'ethnicist discourse' that 'was used by colonialist groups to legitimize a certain way of acting toward other groups' (p. 79) and dates back to a long tradition of boundary-tracing to separate autochthonous from migrants at different times in Western history (Fox \& Guglielmo, 2012). In taking this approach, research 
into consumer ethnicity has overlooked the dominant population's ethnicity often reproducing these colonialist positions. This article contends that, regardless of nationality and power positions, everybody has an ethnicity, which is potentially consequential for their life and consumption. By discussing migrants' and non-migrants' ethnicity in the third part of this article we address implications for personal/collective wellbeing. In order to do so, we review the literature on ethnicity through a broad lens - not only marketing and consumer research but also psychology, sociology, ethnic and critical race studies-including different ontological and epistemological perspectives (positivism, empiricism, interpretivism, etc).

Before proceeding we clarify ethnicity's relationship to ethnic identity. Ethnicity definitions are countless and vary across disciplines, times, and authors due to differing assumptions about the 'nature of ethnicity' (Zmud \& Arce, 1992, p. 443). Building on Bouchet (1995), we also conclude that 'ethnicity' is discursively constructed through the interactions amongst key forces, like political actors (e.g. the role of nation states as producers of ethnic difference versus integrating agents of different ethnic groups) (Verdery, 1994), market agents (Costa \& Bamossy, 1995), and traditional (Downing \& Husband, 2005; Silverstone, 2007) and digital media (Lindridge, Henderson, \& Ekpo, in press). According to the historical and the geocultural context in which such a discourse takes place, some of these forces exert stronger/weaker impact on the construction of ethnicity. For example, Bouchet (1995) observes that contemporary Western societies experience a dominance of the market. Whilst constantly adjusting the notion of ethnicity, these forces tend to stabilize ethnicity in order to preserve long-lasting political, economic, and ideological interests (Lipsitz, 1998) of given, and typically dominating, groups. Unequal access to material and immaterial resources and social opportunities occurs in the presence of 'social boundaries' - 'objectified forms of social differences' (Lamont \& Molnár, 2002, p. 168). However, social boundaries are also determined by forms of 'symbolic boundaries' 
consisting of shared distinctions used to categorize reality and, for our aims, to categorize people on the basis of what is discursively constructed as their ethnicity. As such, (1) ethnicity is 'constructed to last' in order to maintain given privileges; (2) competing constructions of ethnicity express rival interests and power positions; and (3) groups' interests are dissimulated behind discourses of ethnicity such as primordial peoplehood (Barth, 1969; Isajiv, 1974) and often mythicized ancestries (Waters, 1990). We illustrate the role of these, and other, meso and macro forces on the (de)construction of ethnicity in the second part of the article.

At an individual level, people are confronted with different representations of ethnicity, which they subjectively (Laroche, Kim, \& Tomiuk, 1998) and situationally (Stayman \& Deshpande, 1989) adapt to. Wimmer (2008) identifies five different types of personal strategies through which ethnic boundaries are accommodated and modified. In doing so, he supports the existence of personal agency regarding how people relate to existing definitions of ethnicity. The more we enter a multi-ethnic and symbolic society, the more people become ethnic 'bricoleurs' who use ethnicity as a 'totemic' resource to partially strip ethnicity of its historical and cultural meanings to elaborate upon their own 'ethnic style' (Bouchet, 1995). For instance, a person can avoid religious practice but use religious identification as a symbolic resource (e.g. young Arabs of second generation using their Muslim affiliation to challenge rejection from the dominant French society). Hence, at the individual level we locate 'ethnic identity' positions made through the creative assemblage of socially constructed representations of ethnicity/ethnicities. Notably, ethnicity evokes ideas of relative permanence and group privilege whereas ethnic identity evokes ideas of subjectivity and individual agency. Thus, in this article, (1) ethnic identity points to selfascribed cultural origins and not to externally attributed political (e.g. the status of 'foreigner') or biological positions (e.g. the notion of 'race'; Song, 2003); (2) it applies both to migrants and non-migrants; (3) it is an individual response to specific situations (Stayman \& Deshpande, 
1989), social pressures, and multilateral acculturation (Berry, 2006; Molina, Wittig, \& Giang, 2004; Verkuyten, 2005); and (4) it is central to personal as well as social identity (i.e. forms of ‘imagined grouping'; Goldberg, 1992).

The following part of the article comments on different ethnic identity positions people from different ethnicities undertake, some of them directly connected to their (pretended) ancestries and others 'borrowed' from life experience, the market, and/or the media. Given our focus on wellbeing, we ultimately clarify what we mean by wellbeing. Attention for consumer wellbeing has recently re-emerged as a significant concept in consumer research (Mick, 2006). By combining different multidisciplinary approaches such as functionalism, management science, buying-behaviour, macro-marketing, and consumer activism, Pancer and Handelman (2012) explore the historical origins of consumer wellbeing and the factors that have shaped its evolution. The authors highlight that the concept of consumer wellbeing, originally conceived restrictively as the possibility of having more things that a person wants (Riis, 2008), has progressively (1) overcome the economic dimension and (2) included both the personal and the collective sphere. While we align with such a comprehensive definition of consumer wellbeing (economic as well as non-economic; personal as well as collective), we focus on the specific links between consumer wellbeing and ethnicity (Crockett et al. 2011) as an individually and socially constructed category. We show that the way ethnicity is (de)constructed in a given context/time affects possibilities to secure self-identification and thus psychological wellbeing (Phinney, 2005). We also comment on how ethnicity (de)construction conditions collective representations of ethnic groups (Georgiou, 2012), their opportunities of reciprocal (market) acculturation (Berry, 1980), and the nature, extent, and quality of their commercial, social, and cultural exchanges (Peñaloza, 2007). 


\section{The vocabulary on ethnicity in consumer research: Clarifications and extensions}

Unprecedented migration inflows of the past 100 years have spurred research into consumer ethnicity and stimulated both researchers and managers to better understand how people of a different ethnic origin relate to a new (market) culture (Costa \& Bamossy, 1995; Padilla, 1980). This has led to two main consequences. First, migrants and acculturation have been at the centre of the discipline (Luedicke, 2011), and thus made the vocabulary on ethnicity a 'migrant-related language'. Yet, social transformations have shown that ethnicity is a more pervasive phenomenon, where both migrants and non-migrants confront their ethnic identities (Grier, Brumbaugh, \& Thornton 2006; Peñaloza \& Barnhart, 2011) and may act as ethnic 'bricoleurs' (Bouchet, 1995). Second, by maintaining the boundaries of the discipline around migration and acculturation, over the last three decades researchers have generated numerous contributions where the same concepts are used with a variety of often contradictory meanings. As a result, vocabulary on ethnicity/ethnic identity is concurrently too narrow to address the complexity of the field, whilst being overly contradictory.

The first section of the article aims to harmonize existing meanings for key concepts related to ethnicity/ethnic identity, and to include and value emerging concepts that are taking the discussion beyond migration/acculturation and their typical binary oppositions. As such, we do not aim to invent new concepts but to clarify when a given concept should be used, with what meaning, and under what assumptions. All the concepts we list refer to different 'ethnic identities', which people elaborate starting from different 'ethnicities' they find at local, national, transnational, and global level. Table 1 provides a summary of the vocabulary we assemble, where key concepts can be easily compared with reference to: (1) their context of application; (2) the notion(s) of ethnicity they embed; (3) the corresponding ethnic identity positions they stimulate; and (4) their ideological and political underpinnings. Entries are alphabetical. The first 
entry (i.e. 'acculturation') represents a point of departure of the discipline we use as to highlight the novelty and distinctiveness of subsequent concepts. In line with Vygotsky (1978), we also believe that the language we use frames our ability to envisage the world we describe through it. By improving our language, we can limit risks of distored representations, poor conceptualization, and stereotypical explanations, and thus support our ability to represent the people we research more respectfully.

Table 1 about here-

\section{Acculturation and the dominant/dominated scheme}

As stated above, research into consumer ethnicity has long focused on migrants' acculturation, defined as 'the general process of movement and adaptation to the consumer cultural environment in one country by persons from another country' (Peñaloza, 1994, p. 33). In line with Berry's (1980) seminal conceptualization and his subsequent advances $(1997,2008)$, at an individual level, acculturation implies the interaction between a 'culture of origin' and a 'culture of destination' - often qualified as the 'host' culture, which highlights the unfamiliarity and exclusion new-comers may experience. Scholars have also identified a plethora of ethnic identity positions during acculturation (Gudykunst, 1983), ranging from complete assimilation (Wallendorf \& Reilly, 1983) to resistance and rejection (Berry, 1980; Deveraux, 1970). More often, scholars have explored multi-dimensional ethnic identity positions, as in the case of biculturalism (Luna, Ringberg, \& Peracchio, 2008) and cultural swapping (Askegaard et al., 2005; Oswald, 1999), which researchers deem preferable in terms of personal wellbeing (LaFramboise, Coleman, \& Gerton, 1993). Apart from a handful of studies (Grier et al., 2006; Jamal, 2003; Kipnis, Broderick, \& Demangeot, 2013) research has rarely investigated the 'multidirectional cultural adaptation' (Luedicke, 2011, p. 236) - the so-called process of 'reverse 
acculturation' (Kim \& Park, 2009) — through which the local ethnic mainstream acculturates to migrants' ethnicity, thus reducing cultural distance and increasing opportunities of reciprocal exchange.

At a macro level, the 'dominant conceptual scheme' (Peñaloza, 1994, p.34) to discuss acculturation relies on the contrasting notions of 'dominant' (i.e. mainstream) versus 'dominated'(i.e. subcultural) ethnic groups. The implications of this are twofold. First, this scheme frames discussion on ethnicity in conflicting terms. Whilst domination can be also numerical, it is mostly political, social, and economic (Aranowitz, 1992; Healey, 2012). As Lipsitz (1998) argues, appurtenance to the dominant ethnic group in a nation grants a rent position, which mainstream people defend by investing time and energies in the constant (re)creation of their ethnic caste (what he presents as their 'possessive investment'). Second, we argue that the 'dominant'/'dominated' scheme leads to contrast the host culture (that of the dominant ethnic group) to a comprehensive and indistinct culture of the ethnically dominated groups. In doing so, various ethnicities are brought together and flattened.

The 'dominant'/'dominated' scheme also has remarkable implications for wellbeing. Positions of ethnic domination prompt a structured system of privilege reproducing unfair advantages while limiting dominated ethnic groups' opportunities of ownership, education, employment, housing, and health care. Additionally, the common practice of questioning only the ethnicity of dominated minorities undermines ethnic mainstream's salience about its own ethnicity. Recently, Peñaloza and Barnhart (2011) document how middle-class white male consumers in the U.S.A. dominate the North-American credit consumer culture while not perceiving themselves as a group with a clear-cut ethnic identity. Hence, they describe themselves as 'ethnically deficit' persons. On the one hand, limited ethnic salience from the dominant group may result in efforts geared towards maintaining such dominance (e.g. racist 
behaviours). On the other hand, it negatively affects mainstream's wellbeing as a result of diminished ability to discuss their ethnic identity and perception of ethnic depletion.

\section{Cultural sojourning}

As seen, acculturation relies on two key assumptions: (1) ethnicity reconstruction presupposes migration; and (2) migration is a stable, or at least long-lasting, life-stage. Yet, in a globalised world, being a cultural sojourner-someone who temporarily spends time in another country (Sussmann, 2002a) — is an increasingly common feature. One should note that sojourning differs from migration because (1) it does not imply the stabilisation in a different country/culture and (2) it implies a double process of adaptation: first to the new space and later during repatriation (Leong \& Ward, 2000; Lowe, Hwang, \& Moore, 2011; Sussmann, 2002a, 2002b).

Sojourning instead of migration/acculturation should then be preferred to address the ethnic identity position of people living in such situations. A sojourner confronts his/her culture of origin, the host culture as well as a supranational cultural identity platform common to other sojourners around him/her. For example, Teichler (2004) documents how ERASMUS students temporarily studying abroad develop a shared culture that exceeds established national boundaries and identifies an ERASMUS 'way of living'.

With reference to its outcomes, sojourning has been studied in different disciplines. Whilst in policy studies it has been analysed through the lens of the economic and societal implications of temporary or circular migration (McLoughlin \& Muenz, 2011), in social psychology it has been examined with a focus on the dynamics that emerge during cultural contact (Allport, 1954). In her Cultural Identity Model (CIM), Sussmann (2002b) identifies four ethnic identity positions (namely: affirmative, subtractive, additive, and global), which act as predictors of a sojourner's repatriation distress based on acculturation outcomes during host 
country stay. Within consumer research, Tambyah and Chng's (2006) analysis of 14 returning students in Singapore empirically validates and develops Sussmann's (2002a) model. The authors add two types of ethnic identity positions: (1) a resistive shift, when sojourners react aversely to cultural change, and (2) a marginal shift, when sojourners identify with neither home nor host culture ('rootlessness').

Notably, implications for wellbeing refer not only to the moment of temporary sojourn abroad but also to repatriation. Sussmann (2002a) demonstrates that repatriation distress is higher when host culture adaptation is high and identification with home country is low or superseded. Repatriation distress is lower if the sojourners confirm their home identity, either through low levels of adaptation during the sojourn or through providing the complementary cultural identity platform mentioned above. Also, the more overseas experience the sojourner has, the easier both adjustments and adaptation abroad and at home will be (Cui \& Awa, 1992).We suggest that future research can apply the CIM model and its extensions to explore further how cultural sojourners use material and symbolic consumption resources and relate to acculturation agents to express ethnic identification during repatriation in order to improve or sustain their wellbeing.

\section{Cosmopolitanism}

Many different strands of cosmopolitanism exist across disciplines. Recurrent traits attributed to cosmopolitanism include: (1) the habit and interest of travelling abroad (Hannerz, 1996), as a means of cultural enrichment, self-enhancement, and 'worldly enactment' (Thompson \& Tambyah, 1999, p. 217); (2) an acquired mode of practice or a competence to adapt more rapidly and effectively to new cultural contexts (Vertovec \& Cohen, 2002); and (3) an ideological, philosophical, and political project towards multiculturalism that fosters affiliation with likeminded people (Thompson \& Tambyah, 1999). Hence, cosmopolitan people show-or are 
assumed to show — degrees of cultural openness, mixing, and ethnic pluralism (Appadurai, 1996; Calhoun, 2002). Differently from acculturation, cosmopolitanism does not necessarily imply migration. Cosmopolitan people are not socially represented as dominated ethnic groups, being more often described as part of a cultural elite. Differently from cultural sojourning, cosmopolitanism does not imply a temporary stay and repatriation. Instead, it relies on 'proteanism' (Hannerz, 1990), that is, the willingness to inhabit more places and a form of homephobia.

Cosmopolitanism suggests that ethnic identification can emerge beyond previously popular bounded notions of ethnic identity (Brubaker \& Cooper, 2000; Desphande et al., 1986). Notably, cosmopolitanism and cosmopolitan consumption express identification with a place over an ethnic sense of identification with a nation, with consumers drawing from a local, national, and transnational toolkit of cultural resources (Askegaard et al.; 2005; Tonkinwise, 2005). In relation to their original ethnic identity, cosmopolitan identity is paradoxical. At the same time, it presupposes preference for non-local and unfamiliar cultural/ethnic references (i.e. openness to other cultures) but it also implies extensive preference for local and familiar consumptions (i.e. closure on familiar material cultures) to cope with the complexity of constant re-adaptation (Thompson \& Tambyah, 1999).

Implications for wellbeing are straightforward. First, cosmopolitanism invites us to consider that experience in a local place can be more relevant to defining ethnic identity than national or supranational ethnicities. Unsurprisingly, cosmopolitanism has been particularly studied in cities, as these are sites of condensed physical and social spaces where individuals are exposed to a diversity of people, objects, and lifestyles (Sennett, 2002). Second, ethnic identity positions should be conceived as unbounded, emplaced and fluid, with new ethnic identities simultaneously being forged from various cultural sources (Çaglar, 2002; Scheffler, 1999; 
Sennett, 2002). This conceptualisation expands upon Riefler and Diamantopoulos (2009). Third, along with other forms of ethnic identity positions, cosmopolitanism also represents a way of participation in public life in which both consumers and organisations play a role. In a study of media consumption amongst German Turks in Berlin, Çaglar (2002) finds that the consumption of a localised ethnic radio station in Berlin leads to adoption of a localised cosmopolitanism where consumers mix a local perspective with multiple cultural affiliations. The increasing popularity of the radio station has also led to other media outlets in Germany adopting media outputs relevant to German Turks, raising their profile and visibility in public life and thus ultimately affecting their wellbeing.

\section{Global citizenship}

Defining global citizenship is complex. Whilst early conceptions focus on a Western-dominant mind-set (Broeckerhoff \& Wadham-Smith 2007; Hannerz, 1996), recent research argues that new forms of global governance have unequivocally transformed the very notion of global citizenship (Iwabuchi, 2002, 2010). Regardless of the Western/non-Western perspective, global citizenship as a form of ethnic identity position represents a belief in and a sense of belonging to an (imagined) translocal collectivity of like-minded people from around the world (MacDougall, 2003) who, irrespective of nationality, ethnicity and geographical location, share universal ideas, values, beliefs, and modes of living, commonly known as 'global culture' (Beck, 2000; Cornwell \& Stoddard, 2001; Nederveen Pieterse, 2007; Strizhakova, Coulter, \& Price, 2008). Consumption of artefacts such as brands and media assigned with the meaning of 'globalness' is thought to serve as a passport to achieve global citizenship (Strizhakova et al., 2008).

As per cultural sojourning and cosmopolitanism, global citizenship does not imply migration. With reference to cosmopolitanism, global citizenship is also an ideology but: (1) it 
does not rely on the mythology of traveling and exploring different locales; (2) it prefers the global culture that cuts across national and ethnic boundaries to the mix of different local cultures; (3) more than being a philosophical system, it is enacted through ownership and consumption of the (global) material culture; and (4) more than being purely ideological, it supports the political agenda of global citizenship.

With reference to wellbeing, global citizenship stimulates reflexivity on positions of cultural superiority. It holds that global culture is preferable to the local. As mentioned before, the main context of dispute is the extent to which notions of global culture have to reflect a Western versus a non-Western perspective. As non-Western societies boom economically and politically, they increasingly are co-creators of global culture, as reflected by emergent nonWestern consumption artefacts utilizing global meanings (Bengtsson, Bardhi, \& Venkatraman, 2010; Cayla \& Eckhardt, 2007; Eckhardt \& Mahi, 2004; Jafari, Firat, Süerdem, Askegaard, \& Dalli, 2012). These developments de-stabilize the global citizenship discourse in both Western and non-Western societies (Dower, 2003). Specifically, as non-Western societies assume a deWesternized outlook on global citizenship, choices between Western-origin and non-Western origin 'global' brands will increasingly constitute an act of asserting national pride and elevating one's own nation/ethnicity in the global arena (Dong \& Tian, 2009; Venkatesh, Khanwalkar, Lawrence, \& Chen, 2013; Jafari \& Goulding, 2013). Furthermore, Western consumers' responses to non-Western brands are mixed (Melnyk, Klein, \& Volckner, 2012). Whilst undoubtedly there are several contributing factors, this may be reflective of an unwillingness of Western consumers to accept the shifting distribution of power in how global citizenship is defined and created. Overall, by using a global citizenship frame devoid of a West/East divide, we as researchers are better able to understand the dynamic process by which people make meaning using a myriad of cultural objects and practices. 


\section{Hyphenated ethnicity}

As seen, during acculturation the construction of ethnic identity can imply the maintenance of a plurality of ethnicities. Sometimes, one of them dominates the others. For example, Berry (1980) suggests that assimilation to the host culture depends on a migrant's acknowledgement of the superiority of that culture whereas rejection implies a strict preference for the culture of origin. Other times, ethnic identity implies non-hierarchical ordering of different ethnicities with which a person identifies. For example, cultural swapping and biculturalism (LaFramboise et al., 1993; Lau-Gesk, 2003; Luna et al., 2008; Oswald, 1999; Peñaloza, 1994; Tadmor \& Tetlock, 2006) support ethnic pluralism and identity plasticity.

Such an ideological, political, and psychological rejection of hierarchical ordering also occurs in the phenomenon of hyphenated ethnicity, an identity position that entails one's sense of multilocale identification with various equally important ethnic collectivities developed through ancestral links and/or life experiences (Caglar, 1997). Originally, Appadurai (1996) conceptualized hyphenated identity to describe ethnic identity positions of diasporic people (i.e. migrants) who concurrently identify with the culture of putative ethnic origin (delocalized ethnicity by ancestry) and with the new host culture (localized ethnicity by residence). In line with more recent research (Jiménez, 2010; Kipnis et al., 2013), we argue that hyphenated identity does not require a direct migration experience. Factors motivating an extension of the definition include: (1) the rapid rise of mixed-ethnic families (Aspinall, 2003; Clark \& Maas, 2009; Luna \& Peracchio, 2005); (2) acculturation to co-residing (at times multiple) ethnic groups (Jamal, 2003; Luedicke, 2011; Wamwara-Mbugua et al., 2008); (3) short and long-term travels (Bardhi, Eckhardt, \& Arnould, 2012; Bardhi, Ostberg, \& Bengtsson, 2010; Sussmann 2002b); (4) identification with other collectivities' beliefs, rituals and traditions - irrespective of geographical proximity_via media and consumption (Craig \& Douglas, 2006; Iwabuchi, 2010; Oberecker, 
Riefler, \& Diamantopoulos, 2008); and (5) social movement activism and multicultural political ideals (Peñaloza, 2004).

Beyond some analogies, we contend that hyphenated identity does not coincide with acculturation since: (1) hypenahation always implies equal importance among a person's ethnic identities (Phinney, 1989), whereas acculturation may lead to forms of hierarchical nesting (Berry, 1980); (2) hyphenation may not imply a direct migration experience (Kipnis et al., 2013); and (3) despite exceptions (Askegaard et al., 2005), acculturation is typically conceived around two ethnicities, whereas hyphenation expands to a plurality of them. Moreover, hyphenated identity differs from cosmopolitanism and global citizenship since: (1) hypenation is not an ideological, political or philosophical ethnic identity position but a psychological identification with more and equally valued ethnicities acquired through personal life experience (Çaglar, 1997); and (2) whilst global citizenship preaches the superiority of a global consumer culture, hyphenation rejects hierarchization.

Since secure ethnic identity is pivotal for psychological wellbeing (Phinney, 2005), physical and symbolic obstacles to maintain commitment to one or more ethnic collectivities of importance may de-stabilize people of hyphenated ethnicity, with results ranging from passive segregation to violent opposition of communities regarded as enforcers/creators of these obstacles (Berry, 1997; Maalouf, 2000). Conversely, ability to commit to a new collectivity (without required decrease in commitment to other relevant ethnic collectivities) empowers people to develop new skills to achieve belonging (Dona \& Berry, 1994). Therefore, wellbeing for hyphenated people is highly sensitive to national ideologies and sociopolitical governance contexts, which may (not) support its belief in the equality of different ethnicities. For instance, whilst in the U.S.A. hyphenation is a legitimized societal norm (e.g. Irish-American), Europe has a rooted tradition of nation-states, which can more easily support an ideology of national 
sovreignity that stresses 'the potential dangers of multiple loyalties' (Çaglar, 1997, p. 177-178). For example, the French socio-political model encompasses an integrationist view, the idea of French nationality being a sole legitimate descriptor of all citizens. Nevertheless, studies of migrant populations (Ribert, 2006; Simon \& Clément, 2006) reveal a similar patter of identity hyphenation in France and the U.S.A. These investigations confirm the ideological and political use of hyphenated identity with the objective of improving personal and collective wellbeing through rejection of imposed and stigmatizing ethnic identity positions(Simon \& Clément, 2006).

\section{Pan-ethnicity}

Acculturation and hyphenation deploy ethnicities defined at a national level, whereas cultural sojourning, cosmopolitanism, and global citizenship hypothesize the existence of a higher ethnocultural level, which is however defined ideologically (for cosmopolitanism and global citizenship) or existentially (e.g. the ERASMUS culture in the case of cultural sojourning; Teichler, 2004). Differently from former concepts, pan-ethnicity consists in a supranational ethnic identity that, either for personal reasons or for external pressures, people of different nationalities but similar ethnic/racial characteristics are said to share (Lindridge et al., 2013). For example, research on Latinos/as (Castro, 1997; Peñaloza, 1994; Peñaloza and Gilly, 1999) has overcome nationality and questioned to what extent Latinos/as (do not) share given common traits (e.g. stronger family orientation and brand loyalty, when compared to Whites) (Peñaloza, 2004). Also, research into Mediterranean marketing (Cova, 2005) takes the supranational reference of the Mediterranean basin — thus a geo-political and geo-historical reference level—as a collective basis for detecting a shared approach to self-definition, worldview, and attitude to consumption (Carù, Cova, \& Dalli, in press). Then, Mediterranean consumers are said to be more inclined to appreciate slowness of life and consumption, more open to diversity, and particularly 
sensitive to authenticity (Cassano, 1996; Silva, Carù, \& Cova, 2005). Similar discussions hold for Afro-Americans, Blacks outside the U.S.A., Asians, etc. In sum, pan-ethnicity is grounded on race as a socially constructed form of imagined grouping (Song, 2003), which serves as a large dépositoire of common ethnic traits, rituals, norms, and cultural values that people sharing the same supranational identity deploy in order to define themselves and others (Lindridge et al., 2013; Paani, 2001; Visconti, 2005; Wamwara-Mbugua, Cornwell, \& Boller, 2008).

Implications for personal and collective wellbeing depend on the extent to which panethnicity is imposed upon or created by these sub-groups. In this regard, Okamoto (2006) argues that pan-ethnicity is the result of institutional imposition of pan-ethnic categories onto differing ethnic groups. Hence, a national government categorising ethnicities as 'African-Caribbean' or 'South Asian' would be imposing a pan-ethnicity, whilst ignoring the inherent heterogeneity within pan-ethnic groupings. Lopez and Espiritu (1990) show that the more society views differing ethnic groups as a homogenous sub-group, the more likely those groups will develop a pan-ethnic identity. For example, Lee (2000) suggests that Asian sub-groups living in America demonstrate higher levels of intra-group homogeneity based on national boundary categorisations. Min (2010) also documents how pan-ethnicity may be a political-cultural response to discrimination. Pan-ethnicity, therefore, arises from differing ethnic groups recognising that pooling their resources together will produce economic, political, and psychological gains for all. Min's study echoes prior works (Waters, 1999; Woldemikael, 1989), which demonstrate how, unlike their parents, second generation African-Caribbean and Haitians, are unable or unwilling to identify themselves with their parents' nationality, and reluctantly accept the pan-ethnicity categorisation of being 'Black.' 


\section{Transnational ethnicity}

Transnationalism also reflects a plurality of meanings. The foundations of transnationalism date back to the late nineteenth century, when the massive migration of non-Anglo-Saxon migrants from Eastern and Southern Europe to the U.S.A., whilst giving rise to a new American nation (Bourne, 1916), caused apprehension (Nagel \& Staeheli, 2004). More recently, in order to challenge the principles that define a nation, scholars (Glick Schiller, Basch, \& Szanton Blanc,1992; Jusdanis, 2001) have used transnationalism in Western societies as opposed to nationalism. Within research into consumer ethnicity, transnationalism has been restrictively referred to as transnational consumer culture (Askegaard \& Özaglar-Toulouse, 2011; Cayla, \& Eckhardt, 2007; Matthews, 2000; Smith, 1990) and thus associated with—either as a synonym for or a side effect of - globalization.

This overview shows that transnationalism has been used as a synonym of broad migration/acculturation processes (Bourne, 1916; Nagel \& Staeheli, 2004) or as a contemporary expression of global consumer culture and global citizenship (Askegaard \& Özaglar-Toulouse, 2011; Cayla, \& Eckhardt, 2007; Glick Schiller et al., 1992). In line with other scholars (Levitt, 2011; Üçok Hughes and Kjeldgaard; 2006), we also contend that transnationalism is a distinctive concept that should be used more restrictively. Transnationalism highlights the situation of those persons living between two (or more) places, with which they maintain stable relationships (Levitt, 2001). For example, Üçok Hughes and Kjeldgaard (2006) document the dual life of Turkish migrants in Denmark who, by moving back and forth between Denmark and Turkey, maintain enduring social, economic, and cultural connections with both countries. Studies (Nagel \& Staeheli, 2004; Portes, 2001; Rumbaut, 2002; Somerville, 2008) confirm that the possibility of developing a transnational identity is stronger for first generation migrants than for the second generation. Yet, second generations are more likely to develop transnational identities whenever: 
(1) they are fluent and use parents' native language; (2) they make frequent travels to their parents' home country; and (3) they participate in their parents' native consumption practices (Levitt \& Glick-Schiller, 2004; Purkayastha, 2005).

Hence, transnationalism differs from acculturation/migration since: (1) the country of destination is not the unique place of stay; (2) as such, whilst migrants can re-start their life in a new place, transmigrants remain suspended between the places they inhabit; and (3) transmigrants keep updating their cultural endowment in both cultures, which might not be the case for migrants tout-court (especially after family reunion, migrants see their opportunity to be exposed to their culture of origin diminished; Visconti \& Napolitano, 2009). Moreover, transnationalism coincides neither with cosmopolitanism nor with global citizenship since: (1) in line with our definition, it does not imply a philosophical system or a global consumer culture but the two (or more) cultures of the countries of stay; and (2) it presupposes a direct migration experience, which might not be the case for cosmopolitanism and is even less likely to be the case for global citizenship.

Generally, studies (e.g. Reis, Sheldon, Gable, Roscoe, \& Ryan, 2000) in this domain confirm that developing personal relationships within the host context and remaining connected to other cultural backgrounds (i.e. home country) enhance people's sense of wellbeing. Such ties provide people with resources that can help develop coping strategies in dealing with effects of negative life events (Wilkinson, 1999; Wangaruro, 2011) or maintain higher levels of self-esteem (Phinney \& Charia, 1992).

\section{Forces (de)constructing ethnicity and implications for wellbeing}

We already commented that research into consumer ethnicity has only recently started to assess the role of macro institutional forces in the (de)construction of ethnicity in the marketplace. We 
also observed that the few studies holding a macro perspective (Jafari \& Goulding, 2008; Peñaloza and Barnahart, 2011; Peñaloza and Gilly, 1999; Üstüner \& Holt, 2007; Üstüner and Thompson, 2012; Visconti, in press) typically focus on one macro force at a time. However, this limits the ability of our discipline to develop implications for personal and collective wellbeing, because it lacks a holistic view of the many meso/macro forces at play in the (de)construction of ethnicity in the marketplace (Luedicke, 2011).

Moving away from the individual level of analysis in the first part of the article (i.e. ethnic identity positions), in this section we elaborate on the principle of intersectionality that Crockett et al. (2011) recommend. In doing so, we identify the main meso and macro forces that are capable of stimulating the personal and collective (de)construction of ethnicity in the marketplace, and that ultimately impact wellbeing in relation to ethnicity and consumption. As we will elaborate, peoples interactions with these forces can be direct, indirect, observational, or virtual. We contend that at a meso/macro level what stimulates ethnicity (de)construction depends on: (1) the social and historical power dynamics at a given moment (Aronowitz, 1992; Healey, 2012); (2) the representations of ethnicity within social groups and in the media (Downing and Husband; 2005); and (3) the market opportunities that may (not) result for given ethnic groups over time (Costa \& Bamossy, 1995; Grier et al., 2006; Jamal, 2003; Peñaloza, 2004; Peñaloza \& Gilly, 1999). Our proposed model (Figure 1) is intentionally abstract to capture the meso and macro forces applicable to the plurality of ethnic identity positions (acculturation, cultural sojourning, cosmopolitanism, etc.) that we unpacked earlier. Moving from the meso to the macro level, we detail each form of interaction that stimulates ethnicity (de)construction and the implications for personal and collective wellbeing in relation to consumption. We also distinguish between key forces in ethnicity (de)construction and some moderating variables. 


\section{Key meso forces in ethnicity and wellbeing (de)construction}

\section{Ethnicity and wellbeing in family interactions}

In her formative work, Peñaloza $(1989,1994)$ highlights the importance of family when she conceptualizes consumer acculturation processes. In particular, her comments unpack how social interactions within the family transmit consumption knowledge, consumer skills, and behaviours across generations. Whilst migration has a particularly destabilizing role for the structure of migrant families indiscriminately from Western and Eastern cultures, the conclusion of family being the key structure of (consumer) socialisation (Ward, 1974) is not exclusive to migrants. In fact, any family represents a critical site of cultural maintenance, transmission, and rupture from one generation to the next (McCubbin \& McCubbin, 1993). Nonetheless, consumption in a family is used daily to negotiate ethnic boundaries (Lindridge et al. 2004; Sekhon \& Szmigin, 2011). As Lamont and Molnár (2002) observe, mechanisms supporting boundary creation are psychological (e.g. mental processes of categorization), cultural (e.g. interpretive strategies tied to cultural traditions), and structural (e.g. unfair access to resources and opportunities). Hence, it is important to inspect how consumption within the family can attenuate or reproduce ethnic psychological, cultural, and structural boundaries.

It is largely maintained that, regardless of its structure (e.g. dyads or triads) or direct migration experience, each family exerts pressures on its members (Epp \& Price, 2008) to establish a shared ethnicity, as an expression of common heritage and family collective ethnic identity (Lindridge \& Hogg, 2006; Oswald, 1999). As McGoldrick, Giordano, and Garcia-Preto (2005) observe, ethnic identification within the family is a precondition to a person's possibility to develop a 'sense of belonging' to that family. Notably, such process of ethnic identification can become more difficult in situations of migrant families, mixed families, and more broadly for any family living in multicultural societies. Ultimately, a family affects members' wellbeing by 
(de)constructing positive/negative representations of different ethnicities relevant to family members (i.e. 'us' versus 'others'; Valdés, 1996). Consumption visualizes such complex and profound ethnicity-related family dynamics. For example, Oswald (1999) documents how Haitian families migrated to the U.S.A. use consumption within the family to perform a 'culture shopping' (p.310), which is used to negotiate the perceived differences between host and home ethnic identities.

We identify three main types of family interactions central to ethnic consumer wellbeing: marital, generational, and diasporic. First, within marital interactions ethnicity connects to gender roles and structures typical of one or more ethnic collectivities, which also impact (il)legitimate gendered consumptions. The marital dyad can liberate or inhibit a spouse's personal freedom, and may thus contribute to his/her wellbeing stimulating feelings of liberation, frustration or resistance (Chytkova \& Kjeldgaard, 2010; Üstuner \& Holt, 2008). Second, the articulated intergenerational interactions play a crucial role in identity and wellbeing for both parents and their descendants. As cultural gatekeepers, parents orient their children's consumption in ways that confirm or contradict their ethnic heritage (Lindridge \& Hogg, 2006). In the case of migrant families, as 'cross-generational' individuals (Visconti, 2010) children can be 'cultural chameleons' (Sekhon \& Szmigin, 2010) seeking suitable but not easily available products to fit their complex ethnic identity. They can also be agents of acculturation to the local culture for their parents, in particular as soon as they enter the local education system (Favaro, 2009). Third, within the precincts of migration, the remaining diasporic family living in a migrant's country of origin is also influential. Research (Skribis, 2008) shows that the diasporic family maintains an emotional and symbolic influence on migrated family members. This influence is also exerted through the circulation of ethnic goods that reinvigorate memories of ancestral ethnicity (Peñaloza \& Cavazos, 2011). 


\section{Ethnicity and wellbeing at school}

On an international level, scholars have studied the relationship between school/education, ethnicity, and consumption with particular attention on the inclusion of students coming from ethnic minorities and migrant families (Defensor del Pueblo, 2003; Demestrio \& Favaro, 2002; Eurydice, 2004; European Union, 2004; Portes \& MacLeod, 1996). Among them, 'third culture children' research (Cockburn, 2002; Greenholtz \& Kim, 2009) focuses on these young consumers, whom it locates in the midst of parents' culture of origin, host/local culture, and a mix of the two. The uniqueness of their ethnic identity positions has stimulated scholars' interest and creativity in trying to capture their complexity using labels such as: 'second generation', ‘children of migration' or 'children of immigrants' (Portes \& Rumbaut,2001; Rumbaut, 1994), 'post-immigrant generation' (Rumbaut, 2002), ‘cross generation' (Visconti \& Napolitano, 2009),

and indeed 'third culture kids' (Cockburn, 2002; Greenholtz \& Kim, 2009). Alba (2005) shows that the clarity of demarcation between 'third culture children' and their peers belonging to the ethnic mainstream depends on two factors: (1) third culture children's ethnic origin; and (2) the geo-cultural context where demarcation occurs. For example, in the U.S.A. and for children of Mexican origins, the author proves a dominance of 'blurred boundaries'. Differently, in Europe and for children of Muslim origins he observes a prevalence of 'bright boundaries', which exclude any ambiguity about group membership.

We identify two bodies of works within third culture children literature. The first focuses on children's ethnic identities and consumption at school and within the group of peers. It shows that consumption is decisive to manifest, hide, and alter a child's ethnic identity in line with personal identity projects and social pressures. Commonalities in consumption are used to manifest children's solidarity with the group and feel confident with their ethnic identity (Lindridge et al., 2004). Hence, choice and use of goods acquire multiple meanings, which span 
from reciprocal negotiation to gratuity, and from conflicting opposition to mediation among multiple expectations (Visconti, 2010; Visconti \& Napolitano, 2009). Notably, the strength and type of family ties a child has with his/her parents affect his/her tensions with peers (Sekhon \& Szmigin, 2011) since family ties set the boundaries of what can (not) be consumed and with whom. An interesting study on ethnic conflicts at school (Hanish \& Guerra, 2000) in the U.S.A. tests the impact of school context and ethnicity on the likelihood of being victimized by peers. Three 'pan-ethnicities' are compared: African-American, Latinos/as, and Whites. Unsurprisingly, ethnicity predicts the probability of victimization by peers. More counter-intuitively, this study indicates that African-Americans are more exposed to victimization by peers, with Latinos/as less likely to be victimized than White children. Also, the more ethnically integrated the school, the higher White children's risk of being victimized by peers and the lower the risk for AfricanAmericans. These and similar studies have the merit of highlighting key variables that may impact quality of life at school with an immediate impact on a child's wellbeing.

The second stream we detect focuses instead on children's academic performance in relation to ethnicity. This group of studies is relevant for research on both consumption and consumer wellbeing since it assumes that academic performance often predicts future professional opportunities and access to material wealth (i.e. market citizenship). Portes and MacLeod (1996) provide a large-scale test in the U.S.A. on the role of (1) ethnicity, (2) class, and (3) school context in the academic performance of third culture children. First, they find that ethnicity plays a major role, with children belonging to marginal/dominated ethnic groups performing worse academically than children from the ethnic dominant group. Second, parents' social class and education attenuate this negative effect. Third, the school context (inner-city schools, quality of the school, etc.) flattens the negative effect on education performance but only for ethnically disadvantaged children. Valdés' (1996) ethnography of 10 Mexican-born and low- 
income families living at the U.S.A.-Mexican border documents the ambivalence of parents' expectation about children's education. On the one hand, parents understood the risks of school dropout for both children's and family's future possibility to buy and consume. On the other hand, they expressed doubts for the intrinsic value of education since school education can be too abstract in comparison to urgent life needs, including the possibility of granting immediate material subsistence. Generalizing from Valdés, his work shows that several variables affect parents' attitude towards school: (1) parents' educational level; (2) parents' understanding of the rules and aims of the local education system; (3) quality of relations established with teachers; (4) endogenous cultural factors; and (5) actual work opportunities for their children after education. Implications for wellbeing are straightforward. These variables identify key levers that policy makers could and should use to support children's education at family level and beyond, and to eventually support their future opportunities of material wealth. One example is explicative: in 2005, Parisian suburbs (i.e. 'the banlieu') hosted violent riots between second generations and autochthonous French people of the dominant ethnic group. Often presented as an ethnic conflict, these riots are mainly due to the reiteration of mistakes that policy-makers have made with reference to Paris' city governance (Fourcaut, Bellanger, \& Flonneau, 2007), which have limited professional opportunities of second generations in France, despite their level of education and acculturation to the French culture. Ultimately, such conditions do not support parents' positive attitude towards education for their children (Valdés, 1996), thus jeopardizing future opportunities of becoming empowered consumers.

\section{Ethnicity and wellbeing in religious communities}

Research into consumer ethnicity has long questioned the role of religion in relation to ethnicity and consumption. In her investigation of Jewish consumers in the U.S.A., Hirschman (1981) 
suggests that Jewish ethnicity comprises two main axes: Jewish culture and Jewish religion. She also highlights that consumption preferences respond to a person's rate of self-identification with given religious norms (i.e. a 'self-designated religion'). Analogously, in their work on Hispanics in the U.S.A., Desphande et al. (1986, p. 214) provide a Weberian definition of ethnicity that implies appurtenance to common 'religion, values, morality and etiquette.' Similar studies are invaluable for having set the path for subsequent research and for the sensitivity to individual agency in religious identification. Yet, they assume that ethnicity and religion are structurally intertwined - that is, to a given ethnicity corresponds one given religion, to which a person is then free to identify. Social and cultural transformations contradict this tenet, as we increasingly observe people of one ethnic group converting to the religion historically specific of another ethnic group (Rambo, 1993). From a psychological perspective, Paloutzian, Richardson, and Rambo (2001) demonstrate that conversion affects a person's attitudes, emotions, behaviours, and lifestyle - including consumption — but that it does not modify profound personality traits (i.e. the 'Big Five' traits of temperament).

Hence, recent research into consumer ethnicity has tended to maintain a separation between ethnic and religious identity, instead focussing on the "politics of consumer identity work' (Thompson, 2013). Such political use of consumption within the precincts of religion and ethnicity has attracted increasing scholars' attention (Sandikci \& Jafari, 2013; Sandikci \& Rice, 2011). With reference to low-income Muslim consumers in Turkey, Izberk-Bilgin (2012) presents an in-depth exploration of the motivations behind the rejection of 'global brands', which these consumers largely perceive as 'infidel'. Within the same geo-religious context, Sandikci and Ger (2010) document the way middle-class Turkish women negotiate meanings of the veil in a secular urban setting. Their study is particularly interesting as it shows how a typical religious symbol/consumption (i.e. the veil) can be contested within the religious community that is 
supposed to defend it (i.e. Islam). Moreover, this study shows that what becomes a religiously legitimate consumption depends on a convergence of meso/macro forces: (1) religious norms, which should support the consumption of the veil; (2) space, here the secular urban setting, which echoes stigmatization for the veil as a symbol of traditional, rural Islam; (3) social class, which affects a person's power to contradict social and religious norms; and (4) fashion/external culture, which may (not) support deviant religious and consumption behaviours.

The impact of religious communities, both formal and informal (Hirschman, 1981; Jafari \& Goulding, 2008; Nagel \& Staeheli, 2004; Jafari, 2012), on wellbeing is relevant. Jafari et al. (in press) identify three main types of implications. First, they claim that religion can be manipulated for political and ideological reasons, which transform the 'religion' into the 'religious'. In similar contexts, new forms of vulnerability emerge that raise preoccupation for the physical, psychological, economic, and socio-cultural risks they encompass. Second, these authors underline how the marketplace can feed or attenuate religious and ethnic conflicts, through companies' and consumers' use of commodified religious signs and symbols. As Thompson (2013) evokes, consumers with limited access to political channels have often used consumption and the market as 'tools for socio-economic mobilization'. Third, Jafari et al. (in press) invite to consider how modernity is modifying religion. They point out that our liquid society (Bauman, 2005) nurtures forms of hybrid religiosity and hybrid ethnicity, which question the nature and porosity of extant religious and ethnic boundaries, with both opportunities and risks for wellbeing.

\title{
Key macro forces in ethnicity and wellbeing (de)construction
}

\author{
Ethnicity and wellbeing in the marketplace
}


Ethnicity is constantly (de)constructed also within the marketplace. Consumer acculturation research demonstrates that people and organisations operate as acculturation agents by providing migrants with cultural information and behavioural templates for consumption (Peñaloza, 1989). Migrant consumers can draw from different sets of agents, such as home-country agents, hostsociety agents, agents of co-residing ethnic groups, and transnational agents (Askegaard et al., 2005; Peñaloza, 1994; Wamwara-Mbugua et al., 2008). Studies adopting a multilateral acculturation view (e.g. Berry, 1980; Luedicke, 2011) suggest an extended frame of analysis to account for other potential contributors to the (de)construction of ethnicity: (1) non-voluntary agents that exert agency but unintentionally, either due to indifference or to particular selfmotives (Broderick et al., 2011; Kipnis et al., 2013); (2) non-agentic actors that do not actively exert agency but partake in intercultural interactions (Luedicke, 2011; Peñaloza \& Gilly, 1999); and (3) migrant actors that have reciprocal effects on multicultural experiences of non-migrant people (Grier et al., 2006).

Market actors, which interact with and have potential to influence ethnicity (de)construction for both migrant and non-migrant populations, include: (1) human actors (sales personnel, other consumers); (2) material actors (brands, retail and leisure spaces); (3) symbolic actors (advertising and media); and (4) institutional actors. Whilst market actors may perform agentic (voluntary or non-voluntary) and non-agentic functions for different ethnic groups, they all produce and communicate specific cultural meanings that are interpreted by other actors and consumers (McCracken, 1986). For example, Lamont and Molnár (2001) documented how marketing professionals in the U.S.A. participate in the construction and circulation of given representations of Afro-American consumers (e.g. people with a 'stigmatised social identity on their body'; p. 37) as well as in the presumed meanings of consumption for them (e.g. a means to defy racism and express appurtenance to the American middle-class). The authors argue that 
marketing professionals specialized in the Afro-American market-along with AfroAmericans-have an interest in claiming difference between Afro-American consumers and other consumers. A difference that allows for tailored products that leverage on these consumers' lack of social esteem to subsequently increase their willingness to purchase status brands.

Interpretation of cultural meanings may differ across ethnic groups. For example, brand culture literature (Cayla \& Arnould, 2008; Schroeder, 2009; Schroeder \& Salzer-Mörling, 2006) demonstrates that brands as cultural forms evolve differently across cultural contexts since their meanings are embedded in historical, geographical, and socio-cultural specifics. Also, some market actors mediate production and communication of other actors' meanings. For instance, positioning of a cooking sauce brand in the 'ethnic' foods section of a retail space elevates the ethnic element of this brand's meaning in a particular context. Similarly, since people use consumption as a resource for construction and manifestation of their (ethnic) identities (Thompson, 2013), their interpretation of and response to meanings of particular actors may involve meanings' reproduction or alteration to suit their ethnic contexts and worldview.

Furthermore, response to market actors' meanings goes far beyond market transactions. The most recent example is the multi-ethnic makeover given to Elsa the Snow Queen (a princess character in Disney's new animation) by Tumblr users' reflecting their frustration with the lack of ethnic diversity in Disney's movies (Whitelocks, 2013). Finally, actors themselves (e.g. companies) can adapt the meanings they produce and the ways they communicate these meanings to (1) suit newly-evolved realities and (2) extend their agency to more consumer segments. In turn, meaning adaptation evokes different responses from segments for which an actor already performs agentic functions, from segments on which an actor attempts to extend agency, and from segments for which an actor is a non-agent. For example, multiple ethnic backgrounds in advertising has been shown to intensify discriminatory and prejudicial cognitions amongst host 
and migrant ethnic consumer groups irrespective of whether these groups are a target audience (Broderick et al., 2011). Similarly, promotions targeting ethnic groups have been shown to create a backlash from segments of host populations, such as opposition to Halal certified food signage in a supermarket during Ramadan by right-wing non-Muslim consumers in the U.S.A. (Süerdem, 2013).

In sum, the way different market actors produce, reproduce, and exchange consumption meanings has significant social implications for intercultural relations and wellbeing in ethnically diverse societies. Thus, understanding the processes that underlie consumer interpretations and responses to these meanings, and how this interrogates ethnic identity, is foundational for advancing migrants' and non-migrants' wellbeing as well as for orienting how companies can best support consumers' ethnic identity goals.

\section{Ethnicity and wellbeing in the media}

In Silverstone's (2007, p. 5) words, media are 'resources for thought, judgment, and action, both personal and political', which influence public opinion on ethnicity and on how/what different ethnic groups consume. Therefore, they should be seen not only as reflections of pre-existing socio-political realities, but also as constitutive elements in the process of meaning creation in a society (Georgiou, 2012) as well as in a market (McCracken, 1986). Understanding these kinds of judgements becomes critical in ethnically diverse societies and markets. Notably, although these societies and markets claim to hold certain values such as equality, diversity, and multiculturalism, the way they use media frequently produces negative, divisive results.

For instance, Downing and Husband (2005) argue that Western media represent ethnicity unfairly, too often politicizing discussion on ethnicity and increasing the risks of racism surrounding ethnicity discourse. They further posit that when ethnicities are categorised on the 
basis of race, a powerful social category with no scientific reason (Goldberg, 1992), they can be effectively excluded/included from/in social groups. This categorisation then feeds the media's commercial and political agenda with cultural and social representations. Given that the ideological use of race (dis)empowers people based upon their ethnicity, when racial/ethnic representations are institutionalized, they generate feelings of superiority/inferiority among ethnic groups in a given society and market. As Winant $(2000,2005)$ also contends, new metaphors (e.g. nationality and ethnicity) create new types of power domination in social relations with evident implications for wellbeing.

The historical roots of such representations can be found in 'race-thinking'. According to Barzun (1965/1937), such an outlook postulates that, due to their different physical features, human beings are said to belong to stable and separate types. In other words, what differentiates or connects human beings is not their moral values or intellectual capacities but race, a myth historically developed in human society. Media images often demonise these people as 'others' and sometimes 'criminals' and 'undesirables' (King \& Wood, 2001). When such ethnic images are continuously reproduced in the mass media, society's biased perceptions of ethnicity are created, resulting in easier adaptation of institutionalised racism (Downing \& Husband, 2005). Interestingly, migrants themselves can either generate their own media or stick to the home country media. The result of such engagements can be disintegration of the migrants in the host country (King \& Wood, 2001).

Representations of ethnic 'otherness' are also frequent in commercial media. Marketers' decisions about how to segment a market according to consumer ethnicity direct their advertising and communication choices. Instead of facilitating ethnic groups' spontaneous self-ethnic identification (Stayman \& Deshpande, 1989), commercial media tend to impose external representations of ethnic identities (Visconti \& Üçok Hughes, 2011). Lindridge (in press) warns 
against the risks of ethnic segmentation and argues that marketers should consider more attentively to what extent they wish to target ethnic groups via overt ethnic segmentation and communication or instead via product adaptation, which is more neutral in terms of creation of ethnic stereotypes.

Demonization of ethnic groups or migrants may also be related to ideological and political factors that shape migrants' image in the host country. For example, Saeed (2007) demonstrates how the British press often portrays British Muslims as aliens, in line with a new form of racism called 'Islamphobia'. This racism, as Saeed argues, is rooted on the separation between 'Britishness' and 'un-Britishness'. Similarly, Jafari and Goulding (2008) demonstrate how Western media have demonised 'Muslimness', with the effect that Iranian migrants in the UK feel excluded from society and experience increasing anxiety and dislocation. This misrepresentation relies on the West's orientalist approach to Muslim societies, a stance accelerated after 9/11 (Sand1kc1 \& Jafari, 2013), which at the same time serves the double objective of politicizing discussion on certain ethnic groups and stimulating media sales since racism may sell at the level of the marketplace (Bloxham \& Kushner, 1998). These studies necessitate in depth understanding of the role of media in (re)generation of ethnic images and their subsequent implications for personal and collective wellbeing.

\section{Moderating variables}

\section{Identity threats and opportunities}

The way people and groups negotiate tensions arising from identity threats - real or perceived threats posed by ethnic others to one's personal and in-group security - against opportunitiesappraisal of what resources can be gained through different avenues of threats' alleviation or

avoidance_-result in ethnic identity (de)construction (Kosic, Mannetti, \& Lackland, 2005; 
Stephan, Ybarra, \& Bachman, 1999). Integrated Threat Theory (ITT) identifies four types of perceived threats: (1) realistic threats (i.e. threats to political, financial, and material wellbeing); (2) symbolic threats (i.e. perceived violation of cultural values, norms, and practices); (3) intergroup anxiety (i.e. concerns about being embarrassed, rejected, ridiculed or exploited on the basis of a person's ethnic background); and (4) negative stereotypes (i.e. expectations of cultural interactions and justification for prejudice and discrimination) (Stephan,Ybarra, Martnez, Schwarzwald, \& Tur-Kaspa, 1998; Stephan et al., 1999). As mentioned above, consumption can provide either threats and opportunities for ethnic identity.

Psychological stress has profound implications for wellbeing both at a market and social level. From a TCR perspective, the key aspect is how to safeguard personal and collective wellbeing in a stressful ethnicity-related event (Lazarus \& Folkman, 1984; Wang \& Patten, 2001). First, some situational factors such as acuteness, predictability, imminence, and controllability of a stressor, affect the likelihood of (not) controlling the stressful event. Second, personal agency and resources play a significant role. Elaborating upon Hobfoll et al. (Hobfoll, 1989; Hobfoll \& Liebermann, 1987), we suggest protecting and empowering the following personal resources in order to safeguard wellbeing in the instance of ethnic stress: (1) personal resources (self-esteem, skills, and self-efficacy) used to contest being associated with one's ethnic group; (2) energy resources (finances and knowledge); (3) condition resources (relationships, social standing, and status arising from belonging to an ethnic group); (4) object resources (valued possessions and material objects having unique ethnic meanings); and (5) collective support used as a means for attainment/preservation of all other resources. 
Capital, collective efficacy, and collective leverage

In line with Bourdieu (1986), four types of capital are relevant in the (de)construction of ethnic identity and for personal and collective wellbeing: economic, social, cultural, and political capital. Respectively, they consist of: (1) accumulated institutionalized labour convertible into financial terms; (2) accumulated social obligations institutionalized as belonging to a(n) (ethnic) community; (3) accumulated cultural dispositions, rituals, goods, and possessions institutionalized as original properties of a(n) (ethnic) community; and (4) accumulated resources institutionalized as systems deployable to effectively influence policy. When a dominating ethnic group appropriates these capitals exclusively, being accepted as a member of that group is the prerequisite for receiving support, trust, and information sharing. Likewise, inability to access capital makes people susceptible to threats and may drive mobilization of actions to acquire/replenish capital.

Wellbeing is pursued through mobilization, which may consist of: (1) collective efficacy (Crockett et al., 2011) resulting into willingness and capability of a group to support its members and accumulate capital for their in-group; and (2) collective leverage (Guzzini, 2006), which implies acceptance of acquiring/sharing capital from/with ethnic out-groups. Conversely, when collective efficacy and leverage are low, people's mobilization may be directed towards gaining membership in out-groups that are perceived to hold capital. With reference to collective efficacy, dominated ethnic groups have been shown to mobilize ethnic solidarity in economic relations and entrepreneurial activities so to determine enclave economy and ethnic nepotism (Ram, 1994; Salter \& Harpending, 2013; Sanders \& Nee, 1987). For example, with reference to collective leverage, authentic Latino brands and media benefitted from American organizations seeking to strengthen their presence in the American-Latinos market through development of partnership and by providing consultancy (Henstorf, Martinez, \& Merino, 2012). 


\section{Coping strategies}

Coping strategies may be activated as a personal or collective response to alleviate stress related to ethnicity (de)construction. Broadly speaking, these strategies consist of the maintenance of personal and/or collective (material) resources and of the reinterpretation of threats (Hobfoll, 1989), for example, by focusing on what can be gained rather than lost in a particular stressful circumstance. Since 'employing resources for coping is (...) stressful in itself' (Hobfoll, 1989, p. 518), people initially judge the benefits and costs of pursuing coping strategies.

Relying upon acculturation studies (Berry, 1997; Tadmor \& Tetlock, 2006; Triandis, Kashima, Shimada, \& Villareal, 1986; Ward \& Rana-Deuba, 1999) and identity strategies documented within host populations (Arnett, 2002; Druckman, 1994; Oberecker \& Diamantopoulos, 2011; Oberecker et al., 2008; Wallendorf \& Reilly, 1983), we categorize three main types of coping strategies to reduce stress related to ethnic identity (de)construction and to improve personal and collective wellbeing. First, coping may result in extreme ethnic identity change, as in the case of assimilation and marginalization (Berry, 1980) in which consumption is used to visualize such a strategy (Peñaloza, 1994). This coping strategy is more likely to happen whenever adoption of ethnic out-group's (market) identity grants superior opportunities or minimizes losses for the dominated person/in-group. Second, coping may more mildly consist of adaptation or modification of ethnic identity, as in the case of biculturalism and cultural swapping (Luna et al., 2008; Oswald, 1999; Peñaloza, 1994). This type of coping strategy is justified whenever an out-group's granted opportunities or threats are confronted with a personal/ingroup's resources too valuable to lose. Through swapping, a person either shifts between consumptions typical of different ethnic consumer cultures or combines these cultures together. Third, coping can result in affirmation of ethnic identity, as in the case of separation (Dona \& Berry, 1994), nationalism, resistance, and rejection (Berry, 1980; Deveraux, 1970). Again, such 
strategies can use consumption to show national pride and rejection of an ethnic group's consumer culture, as in the case of 'infidel brands' mentioned before (Izberk-Bilgin, 2012). This strategy is likely to emerge in case of insignificant opportunities/threats coming from the outgroup or in case of so highly significant threats to justify reinforced employment of one's own and ethnic in-group resources to withstand the posed threats. Regardless of the type of strategy, coping abilities and effects moderate ethnicity (de)construction as well as personal and collective wellbeing.

\section{History of present}

External forces representing both threats and opportunities for ethnicity (de)construction as well as personal and collective wellbeing are not evaluated equally and permanently as positive/negative by all people since their interpretation is subjective and contextually-specific. For instance, Bhatia and Ram (2009) show how members of the Indian diaspora in the U.S.A. reevaluated their acculturation strategies in light of 9/11. They argue that the idea of invariant acculturation strategies requires re-examination since coping strategies may change gradually or drastically in response to environmental changes. Hence, the meanings consumers attribute to their and others' consumptions can change over time. We define this moderator of ethnicity (de)construction as 'history of present'. Campbell (1998, p. 5) argues that 'neither history of

present is an instance of presentism - where the present is read back into the past - or an instance of finalism, that mode of analysis whereby the analyst maintains that a kernel of the present located in the past has inexorably progressed such that it now defines our condition'. Rather, a history of present represents an incitement from the present that can be traced to how it occurred and gained importance. 
We believe that history of present is a valuable concept advancing that of 'situational ethnicity' (Okamura, 1981; Stayman \& Deshpande, 1989) since it not only highlights importance of the context in which ethnicity is (de)constructed through consumption but also acknowledges the longitudinal aspect of situational variables affecting consumption. Hence, we contend that the focus of the study of ethnicity should shift from identifying types of coping strategies to understanding the circumstantial drivers of threats interpreted as negative or positive stressors.

\section{Conclusions: A TCR agenda for future research into consumer ethnicity}

This article has systematically and critically reviewed research into ethnicity from different disciplines - marketing and consumer research, psychology, sociology, ethnic and critical race studies — and different ontological and epistemological perspectives and approaches — positivist experiments, field work, national data bases, firm and media case studies — towards the dual goals of developing transformative conceptual insights and formulating programmatic research suggestions. The former discussion has extensively addressed the transformative insights for personal and collective wellbeing that we detect at the level of both the vocabulary to describe individual ethnic identity positions and the meso/macro forces (de)constructing representations of ethnicity over time. In the interest of brevity, we do not summarize these implications for personal and collective wellbeing.

Instead, we direct attention to suggestions for future TCR-sensitive research into consumer ethnicity. Consistently with the holistic interpretive model we provide, we encourage creative conceptualizations of personal empowerment and wellbeing that engage with the world as we know it, where consumption and markets are not separate domains for those we study (Peñaloza, 2007; Peñaloza, Toulouse, and Visconti, 2011). Instead, accelerating multicultural 
experience-whether it be as the result of migration and international travel for work opportunity, leisure, family reunification, or to flee economic and political hardship and instability - blurs with uneven labour conditions and skewed distributions of wealth (Reinert, 2007), against a dramatic backdrop of politicians leveraging ethnic strife for political gain (Downing \& Husband; 2005), marketers targeting them with products and services (Costa \& Bamossy, 1995), and a striking contrast of government ideals of equal opportunity with social hierarchy (Mick et al. 2012). A transformative agenda for research into consumer ethnicity is thus grounded on such conditions.

We derive suggestions for future research at both the micro, meso, and macro level. TCR implications at the micro level encourage work that uses the precision of experimental and survey methods to specify the factors, forces, threats, and mediating and moderating relationships among variables, in ways that contribute to deeper understanding of the antecedents and processes of personal ethnic expression, as also captured in Figure 1. Our work documents that, since the foundation of research into consumer ethnicity almost three decades ago, contextual factors as well as individual life conditions have changed at tremendous pace. The fluidity, rapidity, and multiplication of ethnic identity positions and representations of ethnicity in various societies today raise unprecedented questions about how ethnic interactions occur, the way they affect individual ability to and strategies of self-identification, and the extent to which ethnic identity positions and strategies are maintained over time. In some contexts, people make choices about the types of boundaries they try to maintain or attempt to deconstruct (Weinberger, 2012), and these choices affect their wellbeing. Consumption often sits at the nexus of these focal interactions and decisions; it draws focus to ethnic boundaries and often becomes a boundary making or spanning tool. 
We also encourage meso level work attending to collective manifestations of ethnic identity and belonging, as well as fragmentation, disavowal, discriminations, and even violence (Bar-Tal, 1990; Beck, 2010). Such work might explore contemporary patterns of ethnic identity positions and relations between them, as well as more historical group-level, relational identity trajectories in ways that generates particular, context-dependent insights while building robust frameworks for comparative analysis. Further, advancing the meso study of collectivities beyond migrants to include sojourners, cosmopolitans, global citizens, and hyphenated identity formations offers tremendous potential in illuminating the intersectional social relations described by Crockett et al. (2011). It also helps bring to the fore the dramatic scale and scope of transnational and global flows of people and resources that inform emergent and recessive social group formation.

At a macro level, we encourage transformative consumer research to pursue actionoriented case studies within market agents in order to document the personal and organisational activities and ways of thinking that constitute ethnic market targeting programs over time. We invite researchers to engage with ethnic activists and social movements in challenging denigrating representations and formulating new metaphors for ethnic identity and collective development. Another promising possibility is interning in government and non-governmental organisations and educational institutions. In doing so, scholars can gain access and document the development and implementation of ethnic, social and economic policy, where conceptualisation and operationalization at the network-based, system level, are required. Such macro level, transformative work could explore the ways marketing activity as an institutional practice draws from, fosters, and inhibits hierarchical relations between social subgroupings (Lamont \& Molnar, 2002). Also important at this level is conceptualising and empirical examination of the 'unintended effects' of (ethnic) marketing practices and (ethnic) marketing research programs 
(Smith, 2006), to better understand how being researched and targeted as a market affects personal ethnic wellbeing as well as interethnic relations. In line with Saperstein and Penner's work (2012), future research should also consider the mutual influence between the collective construction of ethnicity and conditions of racialized inequality, and between micro individual processes making ethnicity more fluid and macro social stratification effects.

Finally, we strongly encourage all researchers, regardless of their disciplinary appurtenance and level of analysis, to take a reflexive stance in researching ethnicity, examining taken-for-granted presumptions about the 'ethnic consumer', to bring to light how ethnic stereotypes operate in marketing and consumer research, and to bring about more consciously egalitarian forms. Such work need not cast a blind eye to existing social dynamics and hierarchical relations. To the contrary, only by engaging with the world in which we live as it is, inhabiting and exploiting the positions we are trained for in doing research and teaching students, managers, and future executives, may we succeed in transforming ourselves, our work, and the cultural worlds, ethnic social positions, and ethnic identities which we inhabit. 


\section{References}

Alba, R. (2005). Bright vs. blurred boundaries: Second generation assimilation and exclusion in France, Germany, and the United States. Ethnic and Racial Studies, 28(January), 20-49. doi: $10.1080 / 0141987042000280003$

Allport, G.W. (1954). The nature of prejudice. (25 ${ }^{\text {Th }}$ Anniversary Edition, 1974). New York: Basic Books.

Appadurai, A. (1996). Modernity at large: Cultural dimensions of globalization. Minneapolis, Minnesota University of Minnesota Press.

Arnett, J.J. (2002). The psychology of globalization. American Psychologist, 57, 774-783. doi: 10.1037/0003-066X.57.10.774

Askegaard, S., \& Özaglar-Toulouse, N. (2011). Still crossing borders: Migration, consumption, and markets. Consumption Markets \& Culture, 14, 217-222. doi:10.1080/10253866.2011.574823

Askegaard, S., Arnould, E.J., \& Kjeldgaard, D. (2005). Postassimilationist ethnic consumer research: Qualifications and extensions. Journal of Consumer Research, 32, 160-170. doi: $10.1086 / 426625$

Askegaard, S., Kjeldgaard, D., \& Arnould, E.J. (2009). Reflexive culture's consequences. In C. Nakata (Ed.), Beyond Hofstede: Culture frameworks for global marketing and management (pp. 101-124). New York: Palgrave Macmillan.

Aspinall, P.J. (2003). The conceptualisation and categorisation of mixed race/ethnicity in Britain and North America: Identity options and the role of the state. International Journal of Intercultural Relations, 27, 269-296. doi: 10.1016/S0147-1767(03)00012-9

Bardhi, F., Eckhardt, G.M., \& Arnould, E.J. (2012). Liquid relationship to possessions. Journal of Consumer Research, 39, 510-529. doi: 10.1086/664037

Bardhi, F., Ostberg, J., \& Bengtsson, A. (2010). Negotiating cultural boundaries: Food, travel and consumer identities. Consumption, Markets \& Culture, 13, 133-157. doi:10.1080/10253860903562148Bar-Tal, D. (1990). Causes and consequences of delegitimization: Models of conflict and ethnocentrism. Journal of Social Issue, 46(1), 6581. doi: 10.1111/j.1540-4560.1990.tb00272.x

Barth, F. (1969) (Ed.). Ethnic groups and boundaries: The social organization of cultural difference. London: Allen \& Unwin.

Barzun, J. (1965/1937). Race: A study in superstition. Revised, with a new preface "Racism today". New York: Harper Torchbooks.

Bauman Z. (2005). Liquid Life. Malden, MA: Polity Press.

Beck, U. (2000). What is Globalization? Cambridge: Polity Press.

Beck, U. (2010). A God of One's Own: Religion's Capacity for Peace and Potential for Violence. Cambridge: Polity.

Bengtsson, A., Bardhi, F., \& Venkatraman, M. (2010). How global brands travel with consumers: An examination of the relationship between brand consistency and meaning across national boundaries. International Marketing Review, 27, 519-540. doi: 10.1108/02651331011076572

Berry, J.W. (1980). Acculturation as adaptation. In A.M. Padilla (Ed.), Acculturation: Theory, Models, and Some New Findings, (pp. 9-26). Boulder: Westview Press.

Berry, J.W. (1997). Immigration, acculturation, and adaptation. Applied Psychology, 46, 5-34. doi: 10.1111/j.1464-0597.1997.tb01087.x 
Berry, J.W. (2006). Mutual attitudes amongst immigrants and ethnocultural groups in Canada. International Journal of Intercultural Relations, 30, 719-734. doi: 10.1016/j.ijintrel.2006.06.004

Berry, J.W. (2008). Globalisation and acculturation. International Journal of Intercultural Relations, 32(4), 328-336. doi: 10.1016/j.ijintrel.2008.04.001

Bhatia, S., \& Ram, A. (2009). Theorizing identity in transnational and diaspora cultures: A critical approach to acculturation. International Journal of Intercultural Relations, 33, 140149. doi: 10.1016/j.ijintrel.2008.12.009 Bloxham, D., \& Kushner, T. (1998). Exhibiting racism: Cultural imperialism, genocide, and representation. Rethinking History: The Journal of Theory and Practice, 2(3), 349-358. doi: 10.1080/13642529809408971

Bobo, L.D., \& Johnson, D. (2000). Racial attitudes in a prismatic metropolis: Mapping identity, stereotypes, competition, and view on affirmative action. In L.D. Bobo, M.L. Oliver, J.H. Johnson Jr., \& A. Valenzuela Jr. (Eds.), Prismatic metropolis: Inequality in Los Angles, (pp. 82-162). New York: Russell Sage Foundation.

Bouchet, D. (1995). Marketing and the redefinition of ethnicity. In J.A. Costa \& G.J. Bamossy (Eds.), Marketing in a multicultural world (pp. 68-104). Thousans Oaks, CA: Sage Publications.

Bourdieu, P. (1986). The forms of capital. In J.G. Richardson (Ed.), Handbook of theory and research for the sociology of education (pp. 241-258). New York: Greenwood Press.

Bourne, R.S. (1916). Trans-national America. The Atlantic Monthly, 118, 86-97.

Broderick, A.J., Demangeot, C., Adkins, N.R., Henderson, G.R., Johnson, G., Kipnis E., Ferguson, N., Pullig C., Mandiberg, J.M., Mueller, R.D., Roy, A., \& Zuñiga, M. (2011). Consumer empowerment in multicultural marketplaces: Navigating multicultural identities to reduce consumer vulnerability. Journal of Research for Consumers 19. Retrieved from http://jrconsumers.com/academic_articles/issue 19/Multicultural_academic5.pdf

Broderick, A.J., Demangeot, C., Kipnis, E., Zuñiga M., Roy, A., Pullig, C., Mueller, R.D., Mandiberg, J.M., Johnson, G., Henderson, G.R., Ferguson, N.S., \& Adkins, N.R. (2011). No Harm done? Culture-based branding and its impact on consumer vulnerability: A research agenda. Social Business, 1, 263-280. doi: 10.1362/204440811X13210328296586

Broeckerhoff, A. \& Wadham-Smith, N. (2007). Volunteering: Global citizenship in action. London: British Council.

Brubaker, R. \& Cooper, F. (2000). Beyond "identity". Theory and Society, 29, 1-47. Retrieved from

http://www.sscnet.ucla.edu/soc/faculty/brubaker/Publications/18 Beyond_Identity.pdf

Caglar, A.S. (1997). Hyphenated identities and the limits of 'culture'. In T. Modood \& P. Werbner (Eds.), The Politics of Multiculturalism in the New Europe: Racism, Identity and Community, (pp. 169-185). London, UK: Zed Books,

Çaglar, A.S. (2002). Media corporatism and cosmopolitanism. In S. Vertovec and R. Cohen (Eds.), Conceiving cosmopolitanism: Theory, context and practice (pp. 180-190). New York: Oxford University Press.

Calhoun, C.J. (2002). The class consciousness of frequent travelers: Toward a critique of actually existing cosmopolitanism. The South Atlantic Quarterly, 101, 869-897. doi: 10.1215/00382876-101-4-869

Campbell, D. (1998). Writing security: United States foreign policy and the politics of identity (Revised ed.). Minneapolis: University of Minnesota Press.

Carù, A., Cova, B., \& Dalli, D. (in press). Mediterranean marketing and southern thinking: Retrospects and Prospects. Journal of Consumer Behavior. doi: 10.1002/cb.1485 
Cassano, F. (1996). Il Pensiero Meridiano. Rome/Bari, IT: Gius. Laterza \& Figli.

Castro, M.J. (1997). Making Pan-Latino. Latino pan-ethnicity and the controversial case of the Cubans. Harvard Latino Law Review, 2(Fall), 179-197.

Cayla, J., \& Arnould, E.J. (2008). A cultural approach to branding in the global marketplace. Journal of International Marketing, 16, 86-112. doi: 10.1509/jimk.16.4.86

Cayla, J., \& Eckhardt, G.M. (2007). Asian brands without borders: Regional opportunities and challenges. International Marketing Review, 24, 444-456. doi: $10.1108 / 02651330710761017$

Chytkova Z., \& Kjeldgaard, D. (2010). The modern woman myth as a means of cosmopolitan culture capital accumulation: A gendered acculturation perspective. In R.W. Belk, K. Grayson, A.M., Muniz, \& H.J. Schau (Eds.), Research in Consumer Behavior Vol. 13, (pp. 199-216). Bingley: Emerald Group Publishing.

Clark, W.A.V., \& Maas, R. (2009). The geography of a mixed-race society. Growth and change, 40, 565-593. doiI: 10.1111/j.1468-2257.2009.00501.x

Cockburn, L. (2002). Children and young people living in changing worlds: The process of assessing and understanding the 'third culture kid'. School Psychology International, 23, 475-485. doi: 10.1177/0143034302234008

Cornwell, G., \& Stoddard, E. (2001). Global multiculturalism: Comparative perspectives on ethnicity, race and nation. Oxford: Oxford University Press.

Costa, J.A. \& Bamossy, G.J. (Eds.) (1995). Marketing in a Multicultural World: Ethnicity, Nationalism, and Cultural Identity. Thousand Oaks, UK: Sage.

Cova, B. (2005). Thinking of marketing in meridian terms. Marketing Theory, 5, 205-214. doi: $10.1177 / 1470593105052476$

Craig, S.C., \& Douglas, S.P. (2006). Beyond national culture: Implications of cultural dynamics for consumer research. International Marketing Review, 23, 322-342. doi: $10.1108 / 02651330610670479$

Crockett, D., Anderson, L., Bone, S.A., Roy, A., Wang, J.J., \& Coble, G. (2011). Immigration, culture, and ethnicity in Transformative Consumer Research. Journal of Public Policy \& Marketing, 30, 47-54. doi: 10.1509/jppm.30.1.47

Cui, G. \& Awa, N.E. (1992). Measuring intercultural effectiveness: An integrative approach. International Journal of Intercultural Relations, 16, 311-328. doi: 10.1016/01471767(92)90055-Y

Dandy, J., \& Pe-Pua, R. (2010). Attitudes to multiculturalism, immigration and cultural diversity: Comparison of dominant and non-dominant groups in three Australian states. International Journal of Intercultural Relations, 34, 34-46. doi: 10.1016/j.ijintrel.2009.10.003Defensor del Pueblo (2003). La Escolarizacion del Alumnado de Origen Immigrante en Espana. Madrid: www.defensordelpueblo.es.

Demetrio, D., \& Favaro G. (2002). Didattica Interculturale. Nuovi Sguardi, Competenze, Percorsi. Milan: FrancoAngeli.

Desphande, R., Hoyer, W.D., \& Donthu, N. (1986). The intensity of ethnic affiliation: A study of the sociology of Hispanic consumption. Journal of Consumer Research, 13, 214-220. Stable URL: http://www.jstor.org/stable/2489227

Deveraux, G. (1970). Essais d'Etnopsychiatrie Générale. Paris: Gallimard.

Dona, G. \& Berry, J.W. (1994). Acculturation attitudes and acculturative stress of central American refugees. International Journal of Psychology, 29, 57-70. doi: $10.1080 / 00207599408246532$ 
Dong, L. \& Tian, K. (2009). The use of Western brands in asserting Chinese national identity. Journal of Consumer Research, 36, 504-523. doi:10.1086/598970

Dower, N. (2003). An introduction to global citizenship. Edinburgh: Edinburgh University Press.

Downing, J., \& Husband, C. (2005). Representing 'race': Racism, ethnicity and the media. London: Sage.

Druckman, D. (1994). Nationalism, patriotism, and group loyalty: A social psychological perspective. International Studies Quarterly, 38, 43-68.

Eckhardt, G.M., \& Mahi, H. (2004). The role of consumer agency in the globalization process in emerging markets. Journal of Macromarketing, 24, 136-146. doi: 10.1177/0276146704269304

Epp, A.M., \& Price, L.L. (2008). Family identity: A framework of identity interplay in consumption practices. Journal of Consumer Research, 35, 50-70. doi: 10.1086/529535

Eurydice (2004). Integrating Immigrant Children into Schools in Europe. Bruxelles, European Commission: www.eurydice.org.

European Union (2004). Handbook on Integration. Bruxelles: http://europa.eu.

Favaro, G. (2009). L'integrazione a scuola tra ostacoli e riuscite. In L.M. Visconti \& E.M. Napolitano (Eds.), Cross Generation Marketing, (pp.327-355). Milan: Egea.

Fourcaut, A., Bellanger, E., \& Flonneau, M. (2007). Paris/Banlieues: Conflits et Solidarités. Paris: Creaphis.

Fox, C., \& Guglielmo, T. (2012). Defining America's racial boundaries: Blacks, Mexicans, and European immigrants, 1890-1945. American Journal of Sociology, 118(2), 327-379. doi: $10.1086 / 666383$

Georgiou, M. (2012). Introduction: Gender, migration and the media. Ethnic and Racial Studies, 35, 791-799. doi:10.1080/01419870.2011.628041

Golberg, D. (1992). The semantics of race. Ethnic and Racial Studies, 15(4), 543-565.

Greenholtz, J., \& Kim, J. (2009). The cultural hybridity of Lena: A multi-method case study of a third culture kid. International Journal of Intercultural Relations, 33, 391-398. doi:10.1016/j.ijintrel.2009.05.00

Grier S., Brumbaugh A.M., \& Thornton, C. (2006). Crossover dreams: Consumer responses to ethnic-oriented products. Journal of Marketing, 70, 35-51. doi: 10.1509/jmkg.70.2.35

Gudykunst, W.B. (1983). Intercultural communication theory: Current perspective Vol. 7. New York: Sage

Guzzini, S. (2006). Applying Bourdieu's framework of power analysis to IR: Opportunities and limits. Paper presented at the International Studies Association, Chicago.

Hannerz, U. (1990). Cosmopolitans and locals in a world culture. Theory, Culture and Society, 7(June), 237-251.

Hannerz, U. (1996). Transnational connections: Culture, people, places. London: Routledge.

Hanish, L.D, \& Guerra, N.G. (2000). The roles of ethnicity and school context in predicting children victimization by peers. American Journal of Community Psychology, 28(2): 201223. doi: 10.1023/A:1005187201519

Henstorf, B., Martinez, A., \& Merino, M. (2012). Know your consumer: Hispanics in the United States: McKinsey \& Company. Retrieved from: http://csi.mckinsey.com/knowledge_by_region/americas/hispanic_consumers_in_the_us

Hirschman, E.C. (1981). American Jewish ethnicity: Its relationship to some selected aspects of consumer behavior. Journal of Marketing, 45, 102-110. Stable URL: http://www.jstor.org/stable/1251545 
Hobfoll, S.E. (1989). Conservation of resources: A new attempt at conceptualizing stress. American Psychologist, 44, 513-524. doi: 10.1037/0003-066X.44.3.513

Hobfoll, S.E., \& Liebermann, J.R. (1987). Personality and social resources in immediate and continued stress resistance amongst women. Journal of Personality and Social Psychology, $52,18-26$.

Isajiw, W.W. (1974). Definitions of ethnicity. Ethnicity, 1, 111-124.

Izberk-Bilgin, E. (2012). Infidel brand: Unveiling alternative meanings of global brands at the nexus of globalization, consumer culture, and Islamism. Journal of Consumer Research, 39(4), 663-687. doi: 10.1086/665413

Iwabuchi, K. (2002). From Western gaze to global gaze. In D. Crane, N. Kawashima, \& K.I. Kawasaki (Eds.), Global culture: Media, arts, policy and globalization (pp. 256-270). London: Routledge.

Iwabuchi, K. (2010). De-Westernization and the governance of global cultural connectivity: A dialogic approach to East Asian media cultures. Postcolonial Studies, 13, 403-419. doi: $10.1080 / 13688790.2010 .518349$

Jackson, S.E., Joshi, A., \& Erhardt, N.L. (2003). Research on team and organizational diversity: SWOT analysis and implications. Journal of Management, 29, 801-830. doi: 10.1016/S0149-2063 $03 \quad 00080-1$

Jafari, A. (2012). Islamic marketing: Insights from a critical perspective. Journal of Islamic Marketing, 3, 22-34. doi: 10.1108/17590831211206563

Jafari, A., Frrat, A.F., Süerdem, A., Askegaard, S., \& Dalli, D. (2012). Non-Western contexts: The invisible half. Marketing Theory, 12, 3-12. doi: 10.1177/1470593111424183

Jafari, A. \& Goulding, C. (2008). 'We are not terrorists!' UK-based Iranians, consumption practices and the 'torn self'. Consumption, Markets and Culture, 11, 73-91. doi: $10.1080 / 10253860802033605$

Jafari, A., \& Goulding, C. (2013). Globalization, reflexivity and the project of the self: A virtual intercultural learning process. Consumption, Markets \& Culture, 16, 65-90. doi: 10.1080/10253866.2012.659435.

Jafari, A., Özhan Dedeoğlu, A., Regany, F., Üstündağli, E., \& Batat, W. (in press). Rethinking religion in the context of ethnicity and wellbeing. Marketing Theory.

Jamal, A. (2003). Marketing in a multicultural world: The interplay of marketing, ethnicity and consumption. European Journal of Marketing, 37, 1599-1620. doi: $10.1108 / 03090560310495375$

Jamal, A., Peñaloza, L.N. \& Laroche, M. (Eds.) (in press). The Routledge companion on ethnic marketing. London: Routledge.

Jiménez, T.R. (2010). Affiliative ethnic identity: A more elastic link between ethnic ancestry and culture. Ethnic and Racial Studies, 33, 1756-1775. doi:10.1080/01419871003678551

Jusdanis, G. (2001). The necessary nation. Princeton: Princeton University Press.

Kim, Y. \& Park, SY. (2009). Reverse acculturation: A new cultural phenomenon examined through an emerging wedding practice of Korean Americans in the United States. Family \& Consumer Sciences Research Journal, 37(3), 359-375. doi: 10.1177/1077727X08330758

King, R. \& Wood, N. (2001). Media and migration: Construction of mobility and difference. London: Routledge.

Kipnis, E., Broderick, A.J., \& Demangeot, C. (2013). Consumer multiculturation: Consequences of multi-cultural identification for brand knowledge. Consumption Markets \& Culture, iFirst. doi:10.1080/10253866.2013.778199 
Kipnis, E., Broderick, A.J., Demangeot, C., Adkins, N.R., Ferguson, N.S., Henderson, G.R., Johnson, G., Mandiberg, J.M., Mueller, R.D., Pullig, C., Roy, A., \& Zuniga, M.A. (2013). Branding beyond prejudice: Navigating multicultural marketplaces for consumer wellbeing. Journal of Business Research, 66, 1186-1194. doi: 10.1016/j.jbusres.2012.08.011

Kosic, A., Mannetti, L., \& Lackland, S.D. (2005). The role of majority attitudes towards outgroup in the perception of the acculturation strategies of immigrants. International Journal of Intercultural Relations, 29, 273-288. doi:10.1016/j.ijintrel.2005.06.004

LaFramboise, T., Coleman, H., \& Gerton, J. (1993). Psychological impact of biculturalism: Evidence and theory. Psychological Bulletin, 114 (3), 395-412.

Lamont, M. \& Molnár, V. (2001). How Blacks use consumption to shape their collective identity: Evidence from marketing specialists. Journal of Consumer Culture, 1(March), 31-45. doi: $10.1177 / 146954050100100103$

Lamont, M. \& Molnár, V. (2002). The study of boundaries in the social sciences. Annual Review of Sociology, 28, 167-195. doi: 10.1146/annuerev.soc.28.110601.141107

Laroche, M., Kim, C., \& Tomiuk, M.A. (1998). Italian ethnic identity and its relative impact on the consumption of convenience and traditional foods. Journal of Consumer Marketing, 15(2), 121-151.

Lau-Gesk, L.G. (2003). Activating culture through persuasion appeals: An examination of the bicultural consumer. Journal of Consumer Psychology, 13, 301-315.

Lazarus, R.S., \& Folkman, S. (1984). Stress, appraisal, and coping. New York: Springer Publishing Company.

Lee, T. (2000). Racial attitudes and the color line(s) at the close of the twentieth century. In P.M. Ong. (Ed.), The state of Asian Pacific America Vol. IV: Transforming race relations. Los Angeles: LEAP Asian American Public Policy Institute and UCLA Asian American Studies Center.

Leong, C-H., \& Ward, C. (2000). Identity conflict in sojourners. International Journal of Intercultural Relations, 24, 763-776. PII: S0147-1767(00)00030-4

Levitt, P. (2001). Transnational migration: Taking stock and future directions. Global Networks: A Journal of Transnational Affairs, 1, 195-216. doi: 10.1111/1471-0374.00013

Levitt, P., \& Glick-Schiller, N. (2004). Conceptualizing simultaneity: A transnational social field perspective on society. International Migration Review, 38, 1002-1039. doi: 10.1111/j.1747-7379.2004.tb00227.xLindridge, A.M. (in press). Ethnic minority market segmentation: Is it really feasible? In A. Jamal, L. Peñaloza, \& M. Laroche (Eds.), The Routledge companion on ethnic marketing, London: Routledge, in press.

Lindridge, A.M., Henderson, G.R., \& Ekpo, A.E. (in press). (Virtual) ethnicity, the Internet and wellbeing. Marketing Theory.

Lindridge A.M., \& Hogg, M.K. (2006). Parental gate keeping in diasporic Indian families: Examining the intersection of culture, gender, and consumption. Journal of Marketing Management, 22, 979-1008. doi:10.1362/026725706778935628

Lindridge A.M., Hogg, M.K., \& Shah, M. (2004). Imagined multiple worlds: How south Asian women in Britain use family and friends to navigate the 'border - crossings' between households and social contexts. Consumption, Markets \& Culture, 7, 211-228. doi:10.1080/1025386042000271342

Lindridge, A., Visconti, L.M., Diabah, B. \& Smith, A. (2013). Native, host and pan-ethnic cultural references: How Ghanaians in the UK bridge, bond, and reject social appurtenances 
via consumption. Paper presented at the Consumer Culture Theory conference, Tucson, AZ.

Lipsitz, G. (1998). The possessive investment in whiteness: How white people profit from identity politics. Philadelphia: Temple University Press.

Lopez, D., \& Le Espiritu, L.(1990). Panethnicity in the United States: A theoretical framework. Ethnic and Racial Studies, 13, 198-224. doi:10.1080/01419870.1990.9993669

Lowe, S., Hwang, K.S., \& Moore, F. (2011). Sensemaking and sojourner adjustment amongst Korean entrepreneurs in London (UK). Culture and Organisation, 17, 31-46. doi: 10.1080/14759551.2011.530743

Luedicke, M.K. (2011). Consumer acculturation theory: (Crossing) conceptual boundaries. Consumption, Markets \& Culture, 14(3), 223-244. doi: 10.1080/10253866.2011.574824

Luna, D., \& Peracchio, L.A. (2005). Advertising to bilingual consumers: The impact of codeswitching on persuasion. Journal of Consumer Research, 31, 760-765. doi: 10.1086/426609

Luna, D., Ringberg, T., \& Peracchio, L.A. (2008). One individual, two identities: Frame switching amongst biculturals. Journal of Consumer Research, 35, 279-293. doi: $10.1086 / 586914$.

Maalouf, A. (2000). In the name of identity: Violence and the need to belong. New York: Arcade Publishing.

MacDougall, J.P. (2003). Transnational commodities as local cultural icons: Barbie dolls in Mexico. Journal of Popular Culture, 37(2), 257-275. doi: 10.1111/1540-5931.00067

Matthews, G. (2000). Global culture/individual identity: Searching for home in the cultural supermarket. New York: Routledge.

McCracken, (1986). Culture and consumption: A theoretical account of the structure and movement of the cultural meaning of consumer goods. Journal of Consumer Research, 13(1), 71-84.

McCubbin, H.I., \& McCubbin, E.A. (1993). Culture, ethnicity and the family: Critical factors in childhood chronic illnesses and disabilities. Pediatrics, 91(5), 1063-1070.

McGoldrick, M., Giordano, J., \& Garcia-Preto, N. (Eds.) (2005). Ethnicity \& Family Therapy. New York, NY: The Guilford Press.

McLoughlin, S., \& Muenz, R. (2011). Temporary and circular migration: Opportunities and challenges (Working Paper No. 35). Brussels: European Policy Centre.

Melnyk, V., Klein, K., \& Volckner, F. (2012). The double-edged sword of foreign brand names for companies from emerging countries. Journal of Marketing, 76(1), 21-37. doi: http://dx.doi.org/10.1509/jm.11.0349

Mick, D.G. (2006). Meaning and mattering through transformative consumer research. In C. Pechmann and L.L. Price (eds.) Advances in Consumer Research, Vol. 33, (pp. 1-4), Provo, UT: Association for Consumer Research.

Mick, D.G. (2006). Introduction: The moment and place for a special issue. Journal of Consumer Research, 35(3), 377-379. doi: 10.1086/591482

Mick, G.D., Pettigrew, S., Pechmann, C., \& Ozanne, J.L. (Eds.). (2012). Transformative consumer research for personal and collective wellbeing. New York: Routledge.

Min, T.E. (2010). Pan-ethnicity amongst Asian Americans and Latinos: Pan-ethnicity as both a dependent variable and independent variable (Doctoral dissertation). Retrieved from http://ir.uiowa.edu/etd/713.

Molina, L.E., Wittig, M.A., \& Giang, M.T. (2004). Mutual acculturation and social categorization: A comparison of two perspectives on intergroup bias. Group Processes Intergroup Relations, 7(3), 239-265. doi: 10.1177/1368430204046110 
Nagel, C.R., \& Staeheli, L.A. (2004). Citizenship, identity, and transnational migration: Arab immigrants to the US. Space and Polity, 8(1), 3-24. doi: 10.1080/13562570410001678860

Nederveen Pieterse, J. (2007). Ethnicities and global multiculture: Pants for an octopus. Lanham: Rowman \& Littlefield.

Oberecker, E.M., \& Diamantopoulos, A. (2011). Consumers' emotional bonds with foreign countries: Does consumer affinity affect behavioral intentions? Journal of International Marketing, 19(2), 45-72. ISSN: 1069-031X

Oberecker, E.M., Riefler, P., \& Diamantopoulos, A. (2008). The consumer affinity construct: Conceptualization, qualitative investigation, and research agenda. Journal of International Marketing, 16(1), 23-56. doi: http://dx.doi.org/10.1509/jimk.16.3.23

Okamoto, D.G. (2006). Institutional panethnicity: Boundary formation in Asian-American organizing. Social Forces, 85(1), 1-25. doi: 10.1353/sof.2006.0136

Okamura, J.Y. (1981). Situational ethnicity. Ethnic and Racial Studies, 4(4), 452-465. doi: 10.1080/01419870.1981.9993351

Oswald, L.R. (1999). Culture swapping: Consumption and the ethnogenesis of middle-class Haitian immigrants. Journal of Consumer Research, 25(4), 303-318. doi: 10.1086/209541

Ozanne, J.L. (2011). Introduction to the special issue on Transformative Consumer Research: Creating dialogical spaces for policy and action research. Journal of Public Policy \& Marketing, 30(1), 1-4.

Paasi, A. (2001). Europe as a social process and discourse: Considerations of place, boundaries and identity. European Urban and Regional Studies, 8(1), 7-28. doi: 10.1177/096977640100800102

Padilla, A.M. (Ed.) (1980). Acculturation: Theory, Models, and Some New Findings. Boulder, CO: Westview Press.

Paloutzian, R.F., Richardson, J.T, \& Rambo, L.R. (2001). Religious conversion and personality change. Journal of Personality, 67(6), 1047-1079. doi: 10.1111/1467-6494.00082

Pancer, E., \& Handelman, J. (2012). The evolution of consumer well-being. Journal of Historical Research in Marketing, 4(1), 177-189. doi: 10.1108/17557501211195118

Peñaloza, L.N. (1989). Immigrant consumer acculturation. In T.K. Srull (Ed.), Advances in Consumer Research: Vol. 16 (pp. 110-118). Provo: Association for Consumer Research.

Peñaloza, L.N. (1994). Atravesando fronteras/border crossings: A critical ethnographic exploration of the consumer acculturation of Mexican immigrants. Journal of Consumer Research, 21(1), 32-54. doi: http://www.jstor.org/stable/2489739

Peñaloza, L.N. (2001). Consuming the West: Animating cultural meaning at a stock show and rodeo. Journal of Consumer Research, 28(3), 369-398. doi: 10.1086/323728Peñaloza, L.N. (2004). Multiculturalism in the new world order: Implications for the study of consumer behaviour. In K. Ekstrom \& H. Brembeck (Eds.), Elusive Consumption: Tracking New Research Perspectives, (pp. 87-109). Oxford, UK: Berg Publishers.

Peñaloza, L.N. (2007). Mainstreet U.S.A. revisited: Market targeting, politics, Latino/a consumer culture, and community. International Journal of Sociology and Social Policy, 27 (5/6), 234-49. doi: 10.1108/01443330710757267

Peñaloza, L.N., \& Barnhart, M. (2011). Living U.S. capitalism: The normalization of credit/debt. Journal of Consumer Research, 38(4), 743-762. doi: 10.1086/660116Peñaloza L.N., \& Cavazos, J. (2011). Here, there, and beyond: Remittances in transnational family consumption. Theoria y Praxis, 10, 131-161.

Peñaloza, L.N., \& Gilly, M.C. (1999). Marketer acculturation: The changer and the changed. Journal of Marketing, 63(1), 84-104. doi: http://www.jstor.org/stable/1251777 
Peñaloza, L.N., Toulouse, N., \& Visconti, L.M. (Eds.) (2011). Marketing Management: A Cultural Perspective. London: Routledge.

Phinney, J. S. (1989). Stages of Ethnic Identity Development in Minority Group Adolescents. The Journal of Early Adolescence, 9(1-2), 34-49. doi:10.1177/0272431689091004

Phinney, J.S. (2005). Ethnic identity in late modern times: A response to Rattansi and Phoenix. Identity, 5(2), 187-194. DOI:10.1207/s1532706xid0502_7

Phinney, J.S., \& Chavira, V. (1992). Ethnic identity and self-esteem: An exploratory longitudinal study Journal of Adolescence, 15(3), 271-281.

Portes, A. (2001). Introduction: The debates and significance of immigrant transnationalism. Global Networks: A Journal of Transnational Affairs, 1(3), 181-193. doi: 10.1111/14710374.00012

Portes, A., \& MacLeod, D. (1996). Educational progress of children of immigrants: The roles of class, ethnicity, and school context. Sociology of Education, 64(4), 255-275. doi:

Portes, A., \& Rumbaut, R.G. (Eds.) (2001). Ethnicities. Children of Immigrants in America. New York, NY: University of California Press.

Purkayastha, B. (2005). Negotiating ethnicity: Second generation South Asians Americans traverse a transnational world. New Brunswick: Rutgers University Press.

Ram, M. (1994). Unravelling social networks in ethnic minority firms. International Small Business Journal, 12(1), 42-53. doi: 10.1177/0266242694123004

Rambo, L.R. (1993). Understanding Religious Conversion. New Haven, CT: Yale University Press.

Reinert, E. (2007). How Rich Countries Got Rich... and Why Poor Countries Stay Poor. London, UK: Constable.

Reis, H., Sheldon, K., Gable, S., Roscoe, J., \& Ryan, R. (2000). Daily wellbeing: The role of autonomy, competence, and relatedness. Society for Personality and Social Psychology, 26(4), 419-435. doi: 10.1177/0146167200266002

Ribert, E. (2006). Liberté, égalité, carte d'identité : Les jeunes issus de l'immigration et l'appartenance nationale, Paris: La Découverte.Riefler, P., \& Diamantopoulos, A. (2009). Consumer cosmopolitanism: Review and replication of the CYMYC scale. Journal of Business Research, 62(4), 407-419. doi: 10.1016/j.jbusres.2008.01.041

Riis, J. (2008). Consumption, health, and consumer wellbeing. In A. Lee \& D. Soman (Eds.), Advances in Consumer Research, Vol. 35 (pp. 72-75), Provo: Association for Consumer Research.

Rumbaut, R.G. (1994) The crucible within: ethnic identity, selfesteem, and segmented assimilation among children of immigrants. International Migration Review 28, 748-794.

Rumbaut, R.G. (2002). Severed or sustained attachments? Language, identity, and imagined communities in the post-immigrant generation. In P. Levitt \& M.C. Waters (Eds.), The changing face of home: The transnational lives of the second generation (pp. 43-95). New York: Russell Sage Foundation.

Saeed, A. (2007). Media, racism and Islamophobia: The representation of Islam and Muslims in the media. Sociology Compass, 1(2), 443-462. doi: 10.1111/j.1751-9020.2007.00039.x

Salter, F., \& Harpending, H. (2013). J.P. Rushton's theory of ethnic nepotism. Personality and Individual Differences, 55(3), 256-260. doi: 10.1016/j.paid.2012.11.014

Sanders, J.M., \& Nee, V. (1987). Limits of ethnic solidarity in the enclave economy. American Sociological Review, 52(6), 745-773. 
Sandikcı Ö., \& Ger, G. (2010). How does a stigmatized practice become faschionable? Journal of Consumer Research, 37(1), 15-36. doi: 10.1086/649910

Sand1kc1, Ö., \& Jafari, A. (2013). Islamic encounters in consumption and marketing. Marketing Theory, 13(4), 211-220. doi: 10.1177/1470593111423329

Sandikcı Ö., \& Rice, G. (Eds.) (2011). Handbook of Islamic Marketing, Cheltenham, UK : Edward Elgar Publishing.

Saperstein, A., \& Penner, A.M. (2012). Racial fluidity and inequality in the United States. American Journal of Sociology, 118(November), 676-727. doi: 10.1086/667722

Scheffler, S. (1999). Conceptions of cosmopolitanism. Utilitas, 11(3), 255-276. doi: http://dx.doi.org/10.1017/S0953820800002508

Schiller, G., Basch, N.L., \& Blanc, C.S. (1992). Towards a transnational perspective on migration. Race, class, ethnicity, and nationalism reconsidered, New York: New York Academy Series.

Schroeder, J.E. (2009). The cultural codes of branding. Marketing Theory, 9, 123-126. doi: $10.1177 / 1470593108100067$

Schroeder, J.E., \& Salzer-Mörling, M. (Eds.). (2006). Brand culture. Abingdon: Routledge.

Sekhon Y.K, \& Szmigin, I. (2011). Acculturation and identity: Insights from second generation Indian Punjabis. Consumption, Markets \& Cultures, 14(1), 79-98. doi: $10.1177 / 1470593108100067$

Sennett, R. (2002). Cosmopolitanism and the social experience of cities. In: S. Vertovec \& R. Cohen (Eds.), Conceiving cosmopolitanism: Theory, Context and Practice (pp. 42-47). Oxford: Oxford University Press.

Silva F., Carù, A., \& Cova, B. (Eds.) (2005). Marketing Méditerranée et Postmodernité. Editions Marseille, FR: Euromed Marseille.

Silverstone, R. (2007). Media and morality: The rise of the mediapolis. Cambridge: Polity Press.

Simon, P., \& Clément, M. (2006). Comment décrire la diversité des origines en France ? Une enquête exploratoire sur les perceptions des salariés et des étudiants. Population \& Sociétés, 425, 1-4. ISSN 0187783.

Skribis, Z. (2008). Transnational families: Theorising migration, emotions and belonging. Journal of Intercultural Studies, 29(3), 231-246. doi: 10 1080/07256860802169188

Smith, A.D. (1990). Towards a global culture? In M. Featherstone (Ed.), Global culture: Nationalism, globalization and modernity (pp. 171-192). London: Sage.

Smith, W.A. (2006). Social marketing: An overview of approach and effects. Injury Prevention, 12, 33-43. doi: 10.1136/ip.2006.012864

Somerville, K. (2008). Transnational belonging amongst second generation youth: Identity in a globalized world youth and migration. Journal of Social Sciences, Special Volume No.10, 23-33.

Song, M. (2003). Choosing Ethnic Identity.Cambridge: Polity Press.

Stayman, D.M., \& Deshpande, R. (1989). Situational ethnicity and consumer behaviour. Journal of Consumer Research, 16(3), 361-371.

Stephan, W.G., Ybarra, O., \& Bachman, G. (1999). Prejudice toward immigrants. Journal of Applied Social Psychology, 29(11), 2221-2237. doi: 10.1111/j.1559-1816.1999.tb00107.x

Stephan, W.G., Ybarra, O., Martnez, C.M., Schwarzwald, J., \& Tur-Kaspa, M. (1998). Prejudice toward immigrants to Spain and Israel. Journal of Cross-Cultural Psychology, 29(4), 559576. doi: 10.1111/j.1559-1816.1999.tb00107.x 
Strizhakova, Y., Coulter, R.A., \& Price, L.L. (2008). Branded products as a passport to global citizenship: Perspectives from developed and developing countries. Journal of International Marketing, 16, 57-85. ISSN: 1069-031X

Sussman, N.M. (2002a). Sojourners to another country: The psychological roller-coaster of cultural transitions. In W.J. Lonner, D.L. Dinnel, S.A. Hayes, \& D.N. Sattler (Eds.),Online readings in psychology and culture (Unit 8, Chapter 1). Retrieved from http://www.wwu.edu/ culture

Sussmann, N.M. (2002b). Testing the cultural identity model of the cultural transition cycle: Sojourners return home. International Journal of Intercultural Relations, 26(4), 391-408.

Süerdem, A. (2013). Yes my name is Ahmet, but please don't target me. Islamic marketing: Marketing Islam ${ }^{\mathrm{TM}}$ ? Marketing Theory, 13(4), 285-295. doi: 10 1177/1470593113499701

Tadmor, C.T., \& Tetlock, P.E. (2006). Biculturalism: Model of the effects of second-culture exposure on acculturation and integrative complexity. Journal of Cross-Cultural Psychology, 37(2), 173-190. doi: 10.1177/0022022105284495

Tambyah, S., \& Chng, R. (2006). Revisiting the cultural identity model: Sojourners' negotiations of identity and consumption experiences. In C. Pechmann \& L. Price (Eds.), Advances in Consumer Research: Vol. 36 (pp. 464-465). Provo: Association for Consumer Research.

Teichler, U. (2004). Temporary study abroad: The life of ERASMUS students. European Journal of Education, 39(4), 395-408. doi: 10.1111/j.1465-3435.2004.00193.x

Thompson, C.J. (2013). JCR research curations. The politics of consumer identity work. Journal of Consumer Research, available online: http://www.ejcr.org/curations-7.html

Thompson, C.J., \& Tambyah, S.K. (1999). Trying to be cosmopolitan. Journal of Consumer Research, 26(3), 214-241. doi: 10.1086/209560

Tonkinwise, S. (2005). Thingly cosmopolitanism: Caring for the other by design.

(Opening keynote to the "Cosmopolitanism and Place: Designs of Resistance" conference, University of Technology, Sydney, October 2005). Retrieved from http://www.iade.pt/designist/issues/000 10.html

Triandis, H.C., Kashima, Y., Shimada, E., \& Villareal, M. (1986). Acculturation indices as a means of confirming cultural differences. International Journal of Psychology, 21(1-4), 4370. doi: 10 1080/00207598608247575

Üçok Hughes M., \& Kjeldgaard, D. (2006). Consumption in transnational social spaces: A study of Turkish transmigrants. In: E. Karin \& B. Helene (Eds.), European Advances in Consumer Research Vol. 7 (pp. 431-437), Provo: Association for Consumer Research.

Üstüner, T., \& Holt, D.B. (2007). Dominated consumer acculturation: The social construction of poor migrant women's consumer identity projects in a Turkish squatter. Journal of Consumer Research, 34(1), 41-56. doi: 10.1086/513045

Üstüner, T., \& Thompson, C.J. (2012). How marketplace performances produce interdependent status games and contested forms of symbolic capital. Journal of Consumer Research, 38(5), 796-814. doi: 10.1086/660815

Valdés, G. (1996). Con Respeto. Bridging the Distances Between Culturally Diverse Families and Schools. An Ethnographic Portrait. New York, NY: Teachers College Press.

Venkatesh, A., Khanwalkar, S., Lawrence, L., \& Chen, S. (2013). Ethnoconsumerism and cultural branding: Designing "Nano" car. Qualitative Market Research: An International Journal, 16(1), 108-119. doi: 10.1108/13522751311289730

Vedery, K. (1994). Ethnicity, nationalism, and state-making. Ethnic groups boundaries: Past and future. In: H. Vermeulen \& C. Govers (Eds.), The anthropology of ethnicity. Beyond "ethnic groups and boundaries" (pp. 33-58). Cambridge, UK: Cambridge University Press. 
Verkuyten, M. (2005). Ethnic group identification and group evaluation amongst minority and majority groups: Testing the multiculturalism hypothesis. Journal of Personality and Social Psychology, 88(1), 121-138. doi: 10.1037/0022-3514.88.1.121

Vertovec, S., \& Cohen, R. (2002). Introduction: Conceiving cosmopolitanism. In: S. Vertovec \& R. Cohen (Eds.), Conceiving cosmopolitanism: Theory, Context and Practice (pp. 1-22). Oxford: Oxford University Press.

Visconti, L.M. (2005). L'individualisme postmoderne et la pensée méditerranéenne : Oxymore et réconciliation par une approche de cultural-crossing. In F. Silva, A. Carù, \& B. Cova (Eds.), Marketing méditerranée et postmodernité (pp. 127-148). Marseille: Edition Euromed Marseille.

Visconti, L.M. (2010). Cross generation: Cultural (in)visibility in the consumption of second generations. In M.C. Campbell, J.Inman, \& R. Pieters (Eds.), Advances in Consumer Research Vol. 37 (pp. 10-14), Provo: Association for Consumer Research.

Visconti, L.M. (in press), Emplaced ethnicity: The role of space(s) on migrants' acculturation. In A. Jamal, L. Peñaloza, \& M. Laroche (Eds.), The Routledge companion on ethnic marketing, London: Routledge, in press.

Visconti, L.M. \& Napolitano, E.M. (2009). Cross Generation Marketing. Milan: Egea.

Visconti, L.M., \& Üçok Hughes, M. (2011). Segmentation and targeting revisited. In L. Peñaloza, N. Toulouse, \& L.M. Visconti (Eds.), Marketing Management: A Cultural Perspective (pp. 295-314). London: Routledge.Vygotsky, L.S. (1978), Mind and society: The development of higher psychological processes (Edited by M. Cole, V. John-Steiner, S. Scribner, \& E. Souberman). Cambridge: Harvard University.

Wallendorf, M., \& Reilly, M.D. (1983). Ethnic migration, assimilation, and consumption. Journal of Consumer Research, 10(3), 292-302. doi: http://www.jstor.org/stable/2488801

Wamwara-Mbugua, L.W., Cornwell, T.B., \& Boller, G. (2008). Triple acculturation: The role of African Americans in the consumer acculturation of Kenyan immigrants. Journal of Business Research, 61(2), 83-90. doi: http://dx.doi.org/10.1016/j.jbusres.2007.04.011

Wang, J., \& Patten, S.B. (2001). Perceived work stress and major depression in the Canadian employed population, 20-49 years old. Journal of Occupational Health Psychology, 6(4), 283-289.doi: 10.1037/1076-8998.6.4.283

Wangaruro, J. (2011). "I have two homes": An investigation into the transnational identity of Kenyan migrants in the United Kingdom (UK) and how this related to their wellbeing (Unpublished doctoral dissertation). Middlesex University, UK.

Ward S. (1974). Consumer socialization. Journal of Consumer Research, 1(2), 1-17.

Ward, C., \& Rana-Deuba, A. (1999). Acculturation and adaptation revisited. Journal of CrossCultural Psychology, 30(4), 422-442. doi: http://www.jstor.org/stable/2489100

Waters, M.C. (1990). Ethnic Options. Choosing Identities in America. Berkeley and Los Angeles: University of California Press.

Waters, M.C. (1999). Black Identities: West Indian immigrant dreams and American realities. Boston: Harvard University Press.

Weinberger, M.F., \& Wallendorf, M. (2012). Intracommunity gifting at the intersection of contemporary moral and market economies. Journal of Consumer Research, 39(1), 74-92. doi: 10 1086/662198

Whitelocks, S. (2013). Angry Disney fans create their own ethnic princess after latest film features ANOTHER 'generic' white female. Daily Mail. Retrieved from http://www.dailymail.co.uk/femail/article-2353524/Angry-Disney-fans-create-ethnicprincesses-latest-film-features-ANOTHER-generic-white-female.html 
Wilkinson, R. (1999). Income inequality, social cohesion and health, clarifying the theory: A reply to Muntaner and Lynch. International Journal of Health Services, 29(3), 525-543. doi: 10.2190/3QXP-4N6T-N0QG-ECXP

Wimmers, A. (2008). Elementary strategies of ethnic boundary making. Ethnic and Racial Studies, 31(September), 1025-1055. doi: 10.1080/01419870801905612

Winant, H. (2000). Race and race theory. Annual Review of Sociology, 26(1), 169-185. doi: 10.1146/annurev.soc.26.1.169

Winant, H. (2005). The new politics of race: Globalism, difference, justice. Minneapolis: University of Minnesota Press.

Woldemikael, T.M. (1989). Becoming black Americans: Haitians and American institutions in Evanston, Illinois. New York: AMS Press.

Zmud, J., \& Arce, C. (1992). The ethnicity and consumption relationship. In J.F. Sherry Jr. \& B. Sternthal (Eds.), Advances in Consumer Research (19, pp. 443-449). Provo, UT: Association for Consumer Research. 


\section{Table 1}

A refined vocabulary for research into consumer ethnicity

\begin{tabular}{|c|c|c|c|c|}
\hline Vocabulary & Scope of application & Ethnic references & Identity positions & Implications for wellbeing \\
\hline $\begin{array}{l}\text { Acculturation } \\
\text { (Dominant/dominated } \\
\text { frame) }\end{array}$ & $\begin{array}{l}\text { Long-term migrants versus local dwellers } \\
\text { Typical of confrontations between different ethnic } \\
\text { collectives }\end{array}$ & $\begin{array}{l}\text { - Host culture } \\
\text { - Culture of origin } \\
\text { (often crystallized) } \\
\text { - Ethnic minorities' } \\
\text { meta-culture }\end{array}$ & $\begin{array}{l}\text { - Assimilation } \\
\text { - Resistance/Segreg } \\
\text { ation } \\
\text { - Biculturalism/ } \\
\text { Swapping }\end{array}$ & $\begin{array}{l}\text { Pure, separate, stereotypical, and crystallized ethnic } \\
\text { identities used for political confrontation } \\
\text { Disparities in economic, political, and symbolic power } \\
\text { between different ethnic groups is acknowledged and } \\
\text { contested }\end{array}$ \\
\hline Cultural sojourning & $\begin{array}{l}\text { Sojourners (not migrants) } \\
\text { Typical of prolonged stays abroad for study or } \\
\text { work }\end{array}$ & $\begin{array}{l}\text { - Host culture } \\
\text { - Culture of origin } \\
\text { - Sojourners' meta- } \\
\text { culture }\end{array}$ & $\begin{array}{l}\text { - Affirmative } \\
\text { - Subtractive } \\
\text { - Additive } \\
\text { - Global } \\
\text { - Resistive shift } \\
\text { - Marginal shift }\end{array}$ & $\begin{array}{l}\text { Attentive consideration of the effects of adaptation and } \\
\text { repatriation on personal wellbeing }\end{array}$ \\
\hline Cosmopolitanism & $\begin{array}{l}\text { Protean travellers (not migrants) } \\
\text { Typical of multicultural societies offering an array } \\
\text { of ethnic/cultural references }\end{array}$ & $\begin{array}{l}\text { - Local culture } \\
\text { - Multiple cultures } \\
\text { - Cosmopolitan } \\
\text { culture }\end{array}$ & $\begin{array}{l}\text { - Cosmopolitan } \\
\text { identity (multi- } \\
\text { space-related) }\end{array}$ & $\begin{array}{l}\text { Boundary-less ethnic identity with liberatory effects for } \\
\text { personal and collective wellbeing }\end{array}$ \\
\hline Global citizenship & $\begin{array}{l}\text { (Migrants) and non-migrants } \\
\text { Often idealized appurtenance to a community of } \\
\text { like-minded people } \\
\text { Typical of markets experiencing a global culture }\end{array}$ & $\begin{array}{l}\text { - Global culture } \\
\text { (overarching } \\
\text { culture) }\end{array}$ & $\begin{array}{l}\text { - Imagined translocal } \\
\text { identity }\end{array}$ & $\begin{array}{l}\text { Sense of personal and collective empowerment with like- } \\
\text { minded people through imagined citizenship and global } \\
\text { consumer culture } \\
\text { Confrontation between a Western and a non-Western } \\
\text { definition of global citizenship that challenges national pride }\end{array}$ \\
\hline Hyphenated ethnicity & $\begin{array}{l}\text { Frequent migrants, frequent long-term } \\
\text { sojourners, and mixed ethnic families } \\
\text { Typical of people having a multi-ethnic } \\
\text { competence due to life events }\end{array}$ & $\begin{array}{l}\text { - } \text { Multiple local } \\
\text { cultures } \\
\text { - Multiple cultures of } \\
\text { origin }\end{array}$ & $\begin{array}{l}\text { - Hyphenated identity } \\
\text { (alternating and } \\
\text { equally ranked } \\
\text { ethnic identities) }\end{array}$ & $\begin{array}{l}\text { Personal empowerment due to identification and commitment } \\
\text { to multiple ethnic references } \\
\text { Multiple ethnic references are not organised hierarchically }\end{array}$ \\
\hline Pan-ethnicity & $\begin{array}{l}\text { Migrants and non-migrants } \\
\text { Typical of superregional ethnic identities }\end{array}$ & $\begin{array}{l}\text { - Local culture } \\
\text { - (Culture of origin) } \\
\text { - Superregional } \\
\text { meta-culture } \\
\end{array}$ & $\begin{array}{l}\text { - Pan-identity } \\
\text { (convergent ethnic } \\
\text { identities) }\end{array}$ & $\begin{array}{l}\text { Bi-dimensional references for ethnic identity construction are } \\
\text { overcome } \\
\text { Seeks similarity over difference among included groups }\end{array}$ \\
\hline Transnationalism & $\begin{array}{l}\text { Migrant (or second generations) } \\
\text { Typical of a constantly rejuvenated confrontation } \\
\text { with multiple ethnic references }\end{array}$ & $\begin{array}{l}\text { - Local culture } \\
\text { - Culture of origin } \\
\text { (constantly } \\
\text { updated) }\end{array}$ & $\begin{array}{l}\text { - Transnational } \\
\text { biculturalism } \\
\text { (spatial and cultural } \\
\text { alternation) }\end{array}$ & $\begin{array}{l}\text { Extended perception of belongingness and rooting in multiple } \\
\text { ethnic collectives } \\
\text { Higher self-esteem }\end{array}$ \\
\hline
\end{tabular}




\section{Figure 1}

Meso and macro forces (de)stabilizing ethnicity and personal/collective wellbeing

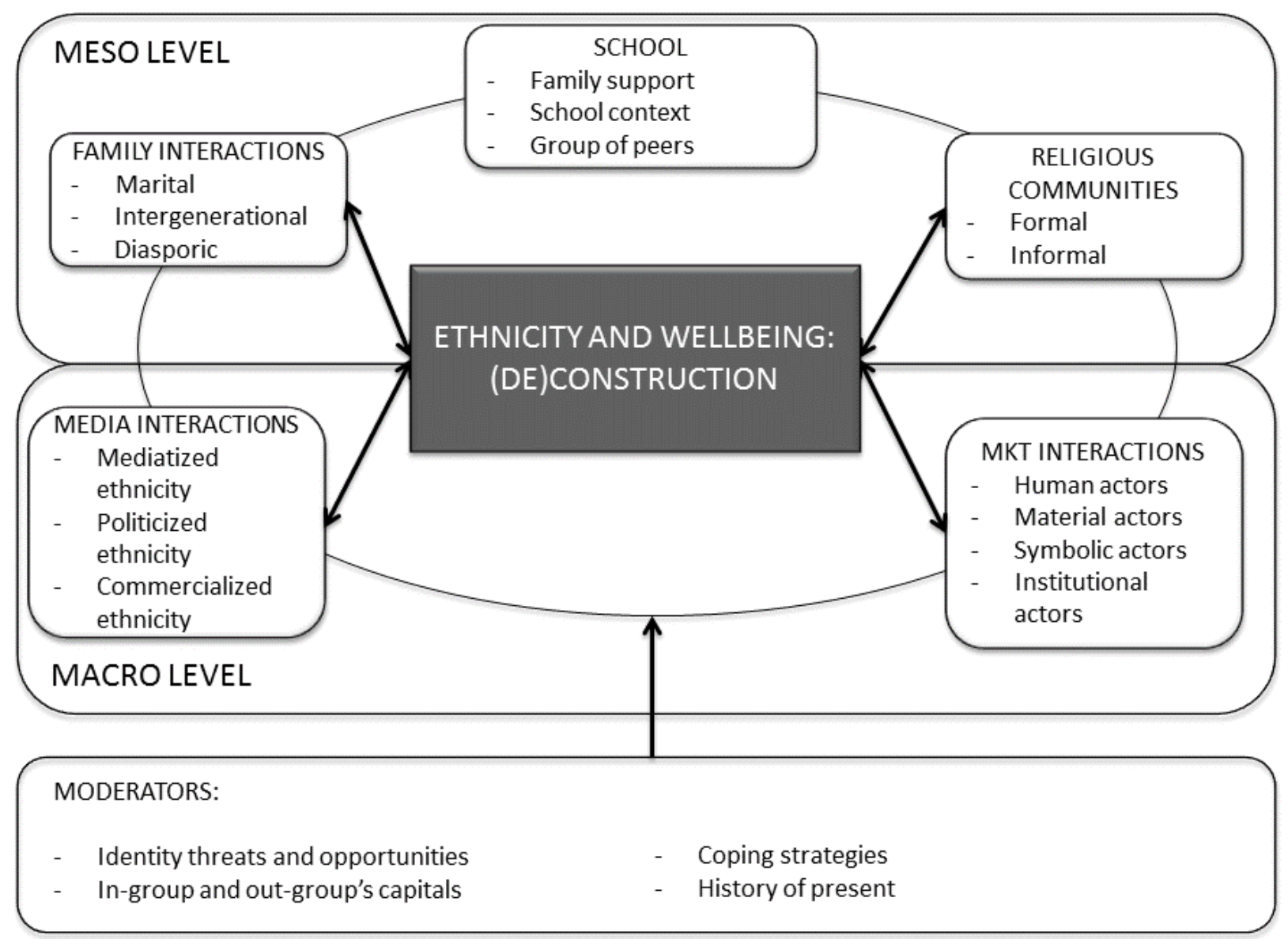

